\title{
A dignidade da pessoa humana e o novo Código de Processo Civil
}

\section{The Human Dignity and the New Civil Procedure Code}

Elias Marques Medeiros Neto

Universidade de Marília, UNIMAR, Marília/SP - Brasil.

André Medeiros Toledo

Universidade de Marília, UNIMAR, Marília/SP - Brasil.

Resumo Após seis anos de tramitação, o projeto de lei que instituiu o novo Código de Processo Civil foi promulgado no ano de 2015. De feitura bastante aberta e democrática, e congregando os valores esposados na Constituição Federal de 1988, o diploma atual inaugura um novo tempo na teoria do processo civil. Tempo de ampliação de direitos fundamentais, tempo de irradiação dos pressupostos axiológicos e dogmáticos do neoconstitucionalismo. Exemplo dessa mudança paradigmática é a criação de um título específico voltado para as normas fundamentais do processo civil que, entre outros preceitos, prevê expressamente que o ordenamento jurídico e as decisões sejam processuais, sejam meritórias, devem resguardar e promover a dignidade da pessoa humana. Entender, portanto, de que forma o processo e tutela jurisdicional será impactado pela valorização das partes, não mais como mero objeto da atividade judicante, mas como sujeito de direito que precisa ser respeitado em sua dignidade, é o principal objetivo deste trabalho. Para tanto, será utilizado o Método Científico Dedutivo, realizando uma análise das principais mudanças previstas na Lei 13.105 de 2015, que enaltecem e privilegiam o princípio da dignidade da pessoa humana no processo. Dessa forma, se chegará à conclusão que o novo Código de Processo Civil, precisamente, anuncia a humanização do processo e o 
entendimento de que o fim último do instrumento estatal de resolução dos litígios é o homem em sua plena dignidade.

Palavras-chave: Novo Código de Processo Civil. Neoconstitucionalismo. Dignidade da Pessoa Humana.

Abstract After six years of debate, the bill establishing the new Civil Procedure Code was enacted in 2015. In a very open and democratic making and bringing the values espoused in the Constitution of 1988, the current law opens a new time in the theory of civil procedure. Fundamental rights of extension of time, irradiation time of axiological and dogmatic presuppositions of neoconstitutionalism. An example of this paradigm shift is the creation of a specific title back to the fundamental rules of civil procedure which, among other provisions, expressly provides that the law and the decisions are procedural, are meritorious, should protect and promote the dignity of the human person. Understand, therefore, how the process and judicial protection will be impacted by the appreciation of the parties, not as a mere object of judicial activity, but as a subject of rights that must be respected in their dignity, is the main objective of this work. Therefore, the Scientific Method Deductive will be used by performing an analysis of the main changes anticipated in Law 13,105 of 2015 praise and favor the principle of human dignity in the process. Thus, it will conclude that the new Civil Procedure Code, precisely, announces the process of humanization and the understanding that the ultimate end of the state instrument of dispute resolution is the man in full dignity.

Key-words: New Code of Civil Procedure. Neoconstitutionalism. DigNiTY OF HUMAN PERSON.

\section{INTRODUÇÃO}

O presente artigo se debruçará sobre o recém-chegado Código de Processo Civil, pontuando - precisamente - acerca da principiologia normativa do novel estatuto processual, enaltecendo a aproximação valorativa deste com a proteção da dignidade da pessoa humana, núcleo central e fulcral dos direitos fundamentais. 
Inicialmente, se buscarão as bases dogmáticas e axiológicas que influenciaram o novo código, partindo da influência das normas constitucionais, do neoconstitucionalismo e, por conseguinte, do atualmente falado neoprocessualismo.

Num segundo momento, dedicado às normas da nova lei processual, se examinará o padrão principiológico que pautou a centralidade e a normatividade das normas processuais fundamentais, assinalando, propriamente, a irradiação da dignidade da pessoa humana na vinculação e resolução das demandas jurídico-processuais.

Por fim, estabelecidas as premissas metodológicas referidas, se analisará de que forma se dará a integração efetiva do princípio da dignidade da pessoa com o processo civil e, também, de como a tutela jurisdicional será impactada pelo vetor do superprincípio ${ }^{1}$ constitucional.

\section{Uma breve história do novo Código de Processo Civil E SUA CONSTITUCIONALIZAÇÃO}

Há muito tempo, teóricos da nova hermenêutica já preconizavam que qualquer apreensão da realidade pressupõe, numa primeira análise, a história que a cunhou. Nesse sentido, por todos, Hans-Georg Gadamer assinalou que "uma hermenêutica adequada à coisa em questão deve mostrar na própria compreensão a realidade da história". ${ }^{2}$

Considerando, portanto, que uma análise da nova lei processual deve guiar-se, inicialmente, pelos pressupostos histórico-jurídicos que a influenciaram, é necessário que se adentre no contexto que determinou a criação do novo Código de Processo Civil.

Nesse norte, o novo diploma processual teve sua tramitação inicial quando da apresentação ao Congresso Nacional de um Anteprojeto do CPC preparado por uma Comissão de Juristas, instalada em 30/9/2009.

SARLET, Ingo Wolfgang. Dignidade da Pessoa Humana e Direitos Fundamentais na Constituição de 1988. Porto Alegre: Livraria do Advogado, 2001, p. 66.

2 GADAMER, Hans-Georg. Verdade e Método: traços fundamentais de uma hermenêutica filosófica. Tradução Flávio Paulo Meurer, 2. ed. Petrópolis: Editora Vozes, 1998, p. 448. 
O Anteprojeto, apresentado em 8 de junho de 2010 ao Senado Federal, sob o número 166/2010, teve seu relatório final exposto em 24 de novembro, e aprovado em 15 de dezembro do mesmo ano.

Após, encaminhado à Câmara dos Deputados, foi instituída nova Comissão de Juristas, em 5 de setembro de 2011, a fim de auxiliar na adequação das possíveis substituições pela Casa do povo. Finalmente, em 26 de março de 2014, o texto foi aprovado e remetido para a sua apreciação final no Senado Federal. Essa casa, por seu turno, aprovou o texto em 17 de dezembro de 2014, tendo sido sancionado pela presidente Dilma Roussef, em 16 de março de 2015.

É certo, evidentemente, que o Novo Código passou por diversas influências nesses quase seis anos em tramitação. A notabilidade dos juristas que participaram da sua redação, cada qual ao seu modo, trouxe uma lei cunhada democraticamente, inclusive com a participação efetiva daqueles que movimentavam diariamente e reconheciam as agruras do Código de 1973.

De igual modo, inclusive, pode-se relembrar que o texto do Anteprojeto ficou disponível para consulta e discussão entre 12 de abril e 15 de maio de 2011 no site do Ministério da Justiça, conferindo verdadeira abertura democrática à consolidação do NCPC.

O Código, nitidamente, procurou alinhar suas normas aos postulados e princípios constitucionais, revelando uma sintonia íntima entre os preceitos do diploma processual e o modelo constitucional do processo.

É nesse sentido que se sustenta a "constitucionalização do direito processual civil", fenômeno nominado por alguns de "neoprocessualismo", cujas premissas derivariam de outro fenômeno, o "neoconstitucionalismo". Tal modelo normativo, nas lições de Luís Roberto Barroso, tem como pressuposto básico, além de outras características, a centralidade dos direitos fundamentais, de modo que o seu caráter ideológico é de concretização efetiva de tais direitos, reafirmando a força normativa da Constituição e a sua consequente densificação. ${ }^{3}$

3 AGRA, Walber de Moura. Curso de Direito Constitucional, 7. ed. Rio de Janeiro: Forense, 2012, p. 45. 
A Constituição, pois, torna-se o ponto de partida e o ponto de chegada para qualquer interpretação e argumentação jurídica, de forma a conferir-lhe eficácia dogmática e valoração na hora de decidir os casos submetidos ao Judiciário. Nessa senda, o processo e a legislação infraconstitucional, portanto, buscam os seus fundamentos de legitimidade e correção na Carta Magna.

É nessa direção o magistério de Eduardo Cambi, para o qual o texto constitucional "não somente por sua posição hierárquica, mas pela quantidade e profundidade das matérias que disciplinou, está no centro do ordenamento jurídico", de modo que não seria possível "compreender o processo, sem antes buscar seus fundamentos de validade - formal e material - na lei fundamental". ${ }^{4}$

O Novo Código de Processo Civil de 2015 rende-se a tais premissas, buscando concretizar os valores dispostos na Constituição de forma apriorística. Nesse sentido, "adota-se como fio condutor, especialmente da atividade judicante, a positivação de um catálogo de direitos fundamentais, pela onipresença, na Constituição, de princípios e regras"5 que vão adquirir concreção infraconstitucional na nova legislação ordinária.

Nesse norte, pode-se afirmar que o modelo constitucional do processo, a que o NCPC se afeiçoa, é o que parte da garantia máxima de acesso à justiça $\left(\mathrm{CF}\right.$, art. $5^{\circ}$., XXXV) e se completa com as garantias, também fundamentais, do devido processo legal (art. $5^{\circ}$., LIV), do contraditório e ampla defesa (art. $5^{\circ}$., LV), da vedação das provas ilícitas (art. $5^{\circ}$., LVI), do juiz natural (art. $5^{\circ}$., XXXVII e LIII), da publicidade dos atos processuais (arts. $5^{\circ}$., LV, e 93, IX), da fundamentação obrigatória das decisões judiciais (CF, art. 93, IX), da assistência jurídica integral e gratuita aos hipossuficientes (art. $5^{\circ}$., LXXIV), da duração ra-

4 CAMBI, Eduardo. Neoconstitucionalismo e Neoprocessualismo. Panóptica, 2007, p. 2. Disponível em: <http:/www.panoptica.org/seer/index.php/op/article/view/ Op_2.2_2007_1-44/64>. Acesso em 25 de maio de 2016.

5 ALVIM, Thereza Arruda. O Novo Código de Processo Civil Brasileiro - Estudos Dirigidos: Sistematização e Procedimentos. Rio de Janeiro: Forense, 2015, p. 280. 
zoável do processo e do emprego dos meios que garantam a celeridade de sua tramitação $\left(\mathrm{CF}\right.$, art. $5^{\circ}$. LXXVIII). ${ }^{6}$

Não obstante isso, o artigo $1^{\circ}$. do novo diploma processual estatui que "o processo civil será ordenado, disciplinado e interpretado conforme os valores e os princípios fundamentais estabelecidos na Constituição da República Federativa do Brasil, observando-se as disposições deste Código". O texto de entrada do NCPC não deixa dúvidas, quer pela posição topográfica, quer por explicitar o alicerce básico do processo, a Constituição, que ele constitui-se no dispositivo central do novo ordenamento processual civil. ${ }^{7}$ Consagra-se, desse modo, a supremacia substancial da Lei Fundamental, apontando-se explicitamente para a constitucionalização do processo.

A norma, relata a doutrina, apesar de ser um preceito evidente e indiscutível, revela-se de verdadeiro caráter didático e instrutivo, demonstrando, assim, que o diploma processual foi concebido e orientado a par e a partir da Constituição Federal, o que é deveras relevante, tendo em vista que este é o primeiro código de processo civil construído e promulgado sob regime democrático - já que os dois anteriores foram concebidos em períodos de regimes autoritários e ditatoriais, 1939 e 1973.

Cassio Scarpinella Bueno, ao comentar o aludido enunciado normativo, informa que ele deve "ser enaltecido e bem compreendido para viabilizar uma interpretação e uma aplicação do CPC de 2015 - e, repito, de todo o direito processual civil -, mais harmônico com os valores do Estado constitucional brasileiro". 8

É nesse sentido também o magistério do Professor Fredie Didier Jr., ${ }^{9}$ tendo em vista, primordialmente, o fato de que:

6 THEODORO JR, Humberto. O Compromisso do Projeto de Novo Código de Processo Civil com o processo justo. Revista de Informação Legislativa, p. 239.

7 Jr., MACHADO, Dario Ribeiro, CARNEIRO, Paulo Pinheiro, PINHO, Humberto Dalla de. Novo Código de Processo Civil - Anotado e Comparado. Rio de Janeiro: Forense, 2015, p. 7.

8 BUENO, Cassio Scarpinella. Manual de processo civil: baseado no novo código de processo civil, 1 ed. São Paulo: Saraiva, 2015, p. 78.

9 CABRAL, Antonio Passo, CRAMER, Ronaldo (orgs.). Comentários ao Novo Código de Processo Civil. Rio de Janeiro: Forense, 2015, p. 15. 
[...] as normas de direito processual civil não podem ser compreendidas sem o confronto com o texto constitucional, sobretudo no caso brasileiro, que possui um vasto sistema de normas constitucionais processuais, todas orbitando em torno do princípio do devido processo legal, também de natureza constitucional.

Na mesma direção é o magistério de Humberto Theodoro Jr., ${ }^{10}$ para o qual:

[...] o Direito Processual Civil brasileiro está hoje totalmente constitucionalizado no campo de seus fundamentos e de sua macroestrutura. Os poderes de acesso à justiça e os deveres de tutela jurisdicional integram as garantias fundamentais proclamadas pelas Constituição de 1988. As leis processuais comuns formam um arcabouço instrumental destinado a disciplinar os aspectos procedimentais para se alcançar a tutela jurisdicional. Mas, em virtude do princípio da supremacia da Constituição, sua interpretação e manejo não podem, de modo algum, contrariar as regras e princípios traçados pela ordem constitucional. Deve-se ter sempre em mente, como ponto de partida, a observância das garantias constitucionais do moderno processo justo, na medida em que insubordinar-se contra a lei ordinária equivale a atentar contra a própria Carta Magna.

Com efeito, a própria Exposição de Motivos do NCPC assentou que a Comissão responsável por sua feitura teve como um dos objetivos "estabelecer expressa e implicitamente verdadeira sintonia fina com a Constituição Federal", de modo a ficar "evidente a harmonia da lei ordinária em relação à Constituição Federal da República". ${ }^{11}$

10 THEODORO JÚNIOR, Humberto. Novo Código de Processo Civil Anotado, 20. ed. Rio de Janeiro: Forense, 2016, p. 16.

11 Disponível em <https:/www.senado.gov.br/senado/novocpc/pdf/Anteprojeto.pdf>. Acesso em: 12 jun. 2016. 
Foi imbuído desse espírito de valorização normativa da Constituição que o novo CPC dedicou seu primeiro capítulo a apresentar um elenco com as normas fundamentais do processo civil brasileiro - artigos $1^{\circ}$. a 12 .

Tais preceitos, consoante Didier, ${ }^{12}$ compõem o chamado "Diploma Processual Fundamental", composto por princípios e regras, que densificam os direitos e garantias fundamentais contidos na Constituição para o processo civil.

Não se descura, entretanto, que tais princípios já vinham sendo analisados. A novidade, na verdade, é que agora se encontram expressamente positivados no novo CPC. Tais contornos do modelo constitucional do processo esculpido na Lei 13.105/2015 têm por fim a formação e o desenvolvimento de um processo justo, que se revela através de uma tutela jurisdicional adequada, efetiva e tempestiva. ${ }^{13}$

Nesse sentido, sobreleva-se - entre outros - o artigo $8^{\circ}$., estatuindo que o juiz, ao aplicar o ordenamento jurídico, "atenderá aos fins sociais e às exigências do bem comum, resguardando e promovendo a dignidade da pessoa humana e observando a proporcionalidade, a razoabilidade, a legalidade, a publicidade e a eficiência". Quanto à primeira parte do preceito, novidade inexiste, afinal, o artigo $5^{\circ}$. da LINDB já trazia a previsão de interpretação teleológica da lei. Todavia, merece atenção o fato de que pela primeira vez o diploma processual traz em seu bojo a previsão de que a dignidade da pessoa humana deverá ser resguardada e promovida.

Está-se diante, inevitavelmente, de preceito de forte cunho constitucional, derivando sua fundamentação do artigo $1^{\circ}$., inc. III, da Constituição Federal que assevera, entre os fundamentos da República Federativa do Brasil, a dignidade da pessoa humana. Desse modo, vislumbra-se com tranquilidade que o novo Código de Processo Civil concebeu o superprincípio constitucional como vetor hermenêutico da maior monta, de forma que o intérprete do novel estatuto processual, ao

12 CABRAL, Antonio Passo, CRAMER, Ronaldo (orgs.). Comentários ao Novo Código de Processo Civil. Forense, 2015, p. 17.

13 MARINONI, Luiz Guilherme; MITIDIERO, Daniel. O projeto do CPC: críticas e propostas. São Paulo: Revista dos Tribunais, 2010, p. 15. 
analisar os pormenores jurídicos do caso submetido a sua apreciação, deverá resguardar e promover a dignidade da pessoa humana.

A propósito, inclusive, o princípio da razoabilidade e o princípio da proporcionalidade, que já figuram como princípios norteadores da Administração Pública, agora aparecem como princípios processuais explícitos no artigo $8^{\circ}$. do novo CPC, imantando toda a atividade jurisdicional.

Entretanto, dada a formalidade e instrumentalidade do processo, pergunta-se: de que maneira a aplicação e concretização do processo civil será impactada pelo ditame constitucional? Está-se diante apenas de cláusula geral sem a menor eficácia? Os meandros do processo é locus possível para a validação da dignidade da pessoa humana?

Antes de perquirir tais interrogações, no próximo capítulo, se analisará precisamente o que vem a ser a dignidade da pessoa humana e de que modo sua pauta valorativa ensejará um correto entendimento e aplicação das normas processuais.

\section{A dignidade da Pessoa humana e o processo CiVIL}

O conceito de dignidade da pessoa humana não é um conceito estanque, que existe aprioristicamente. Muito ao contrário. Sua designação foi sendo composta paulatinamente, fruto de diversas circunstâncias históricas, políticas e sociais. É comum, abalizando a noção de dignidade, socorrer-se a Kant para afirmar que a premissa básica da concepção de dignidade perpassa a ideia de que o ser humano é dotado de dignidade pelo simples fato de ser humano. Diante do homem como fim em si mesmo, compreende-se que a dignidade da pessoa humana é a base do ordenamento jurídico, seu elemento central, de modo que sua centralidade advém de "que nenhuma norma jurídica pode denegrir seu conteúdo essencial" tornando-o, dessa forma, "vetor paradigmático para a interpretação das demais normas e valores constitucionais". ${ }^{14}$

14 AGRA, Walber de Moura. Curso de Direito Constitucional, 7. ed. Rio de Janeiro: Forense, 2012, p. 124. 
Ingo Sarlet, autoridade no tema, afirma que a dignidade da pessoa humana possui força normativa mais intensa que uma simples norma, que, além do seu enquadramento na condição de princípio (valor) fundamental, é substrato de mandamento definidor não somente de direitos e garantias, mas também de deveres fundamentais. ${ }^{15}$

É nesse sentido também o magistério de Bernardo Gonçalves Fernandes, ${ }^{16}$ para o qual:

[...] a dignidade da pessoa humana (art. 1, III da CR/88) é erigida à condição de meta-princípio $($ sic $)$. Por isso mesmo, esta irradia valores e vetores de interpretação para todos os demais direitos fundamentais, exigindo que a figura humana receba sempre um tratamento moral condizente e igualitário, sempre tratando cada pessoa como fim em si mesmo, nunca como meio (coisas) para satisfação de outros interesses ou interesses de terceiros.

Vê-se, portanto, que a dignidade da pessoa humana reveste-se de função essencialmente integradora e hermenêutica, de modo que sua essência serve de substrato para a "aplicação, interpretação e integração não apenas dos direitos fundamentais e das demais normas constitucionais, mas de todo o ordenamento jurídico". Afirma Sarlet, ainda, que de modo todo especial, "o princípio da dignidade da pessoa humana acaba por servir de referencial inarredável no âmbito da indispensável hierarquização axiológica inerente ao processo de criação e desenvolvimento do Direito". ${ }^{17}$

Na mesma direção é o magistério de Daniel Sarmento: ${ }^{18}$

15 SARLET, Ingo Wolfgang. Dignidade da pessoa humana e direitos fundamentais na Constituição Federal de 1988. Porto Alegre: Livraria do Advogado, 2001, p. 70.

16 FERNANDES, Bernardo Gonçalves. Curso de Direito Constitucional, 3. ed. Salvador: Juspodvim, 2013, p. 300.

17 SARLET, Ingo Wolfgang. Dignidade da pessoa humana e direitos fundamentais na Constituição Federal de 1988. Porto Alegre: Livraria do Advogado, 2001, p. 106.

18 SARMENTO, Daniel. A ponderação de interesses na Constituição Federal, 1. ed. - segunda tiragem. Rio de Janeiro: Lumen Juris, 2002, p. 48. 
O princípio da dignidade da pessoa humana representa o epicentro axiológico da ordem constitucional, irradiando efeitos sobre todo o ordenamento jurídico [...] pode ser dito que o princípio em questão é o que confere unidade de sentido e valor ao sistema constitucional, que repousa na ideia de respeito irrestrito ao ser humano - razão última do Direito e do Estado. [...] reiteramos nosso entendimento de que nenhuma ponderação de bens pode implicar em amesquinhamento da dignidade da pessoa humana, uma vez que o homem não é apenas um dos interesses que a ordem constitucional protege, mas a matriz axiológica e o fim último desta ordem.

É certo, portanto, que a dignidade da pessoa humana é tábula vital de todo o arcabouço jurídico, pois é pressuposto e imprescindível para a legitimação das outras normas constitucionais e, sobretudo, das infraconstitucionais.

Desse modo, o processo civil constitucionalizado, conforme já sustentado, deve contaminar-se com os preceitos, valores e princípios esculpidos na Constituição Federal. Ora, se é verdade que a dignidade da pessoa humana é o núcleo central da Lei Fundamental, se é correto afirmar que as leis ordinárias - e aqui, pela especificidade, o novo CPC - devem pautar-se pelos pressupostos constitucionais, então é tranquilo afirmar-se que o novel ordenamento processual tem de se render, nas resoluções dos aspectos processuais e a fim de se atingir uma solução justa, adequada e efetiva, ao postulado da dignidade da pessoa humana.

Dúvidas inexistem, pois, que o processo civil é estruturado a partir dos direitos fundamentais que compõem, nas lições de Marinoni, Mitidiero e Arenhart, o "direito fundamental ao processo justo". Tal premissa significa dizer que o legislador ordinário tem o dever de desenhar as leis infraconstitucionais de acordo e a partir do conteúdo constitucional. Ou seja:

[...] o Código de Processo Civil constitui direito constitucional aplicado. O Código deve ser interpretado de acordo com a Constituição e com os direitos fundamen- 
tais, o que significa que as dúvidas interpretativas devem ser resolvidas a favor da otimização do alcance da Constituição e do processo civil como meio para tutela dos direitos. ${ }^{19}$

É nessa direção e a fim de conferir eficácia aos mandamentos da Constituição, que o novo $\mathrm{CPC}$ trouxe a previsão de várias cláusulas gerais nos seus primeiros artigos, enaltecendo, no ponto, a primazia da dignidade da pessoa humana. Tais preceitos revelam que é fundamental que se busquem soluções adequadas, constitucionalmente legítimas, para os conflitos. ${ }^{20}$

No que se refere, precisamente, ao princípio da dignidade da pessoa humana previsto no artigo $8^{\circ}$. do novo Código, há quem sustente a sua desnecessidade e falta de efetividade. ${ }^{21}$ Entretanto, essa é a posição à qual não nos rendemos, tendo em vista que o dispositivo é primoroso, atuando como guia interpretativo sobre as demais normas do CPC. Nesse sentido, colhe-se a lição cirúrgica de Nelson Rosenvald ${ }^{22}$ que, analisando a norma, estatui que:

O maior cuidado do intérprete é no sentido de jamais banalizar a dignidade, fazendo dela um elixir processual, tal como muitas vezes se vê na esfera do direito civil. Penso que não há maiores dificuldades em transpor

19 MARINONI, Luiz Guilherme; MITIDIERO, Daniel; ARENHART, Sérgio Cruz. Novo Código de Processo Civil comentado, 2. ed. São Paulo: Editora Revista dos Tribunais, 2016, p. 14.

20 CÂMARA, Alexandre Freitas. O Novo Processo Civil Brasileiro, 2. ed. São Paulo: Atlas, 2016, p. 3.

${ }_{21}$ Nesse sentido, Marcelo Magalhães Bonicio - Os princípios do processo no novo código de processo civil, 1. ed. São Paulo: Saraiva, 2016, p. 29 - para o qual, "não há nenhuma situação em que, no processo civil, alguém possa ser submetido a algum tipo de constrangimento que viole a sua dignidade, e isso deixa sem utilidade a intenção do legislador de proteger os direitos humanos dessa forma, inclusive porque o CPC de 1973 sempre foi guiado pela defesa desses direitos".

22 ROSENVALD, Nelson. A dignidade da pessoa humana no CPC/15. Disponível em: <http://www.nelsonrosenvald.info/\#!A-dignidade-da-pessoa-humana-no-CPC15/c21xn/567465c30cf2c2b7798a7adc>. Acesso em 12 jun. 2016. 
a noção constitucional do princípio para, em seguida, adaptá-la às singularidades do processo.

Com efeito, para o artigo $8^{\circ}$., a aplicação do ordenamento jurídico deverá resguardar e promover a dignidade da pessoa humana. Ou seja, o exercício da função jurisdicional deve se pautar, sempre, pelos meandros que resguardem a dignidade da pessoa humana. Sobre o ponto, o Professor Fredie Didier Jr. ${ }^{23}$ nos explica que "resguardar, nesse contexto, é, de um lado, aplicar corretamente a norma jurídica 'proteção da dignidade da pessoa humana' e, de outo, não violar a dignidade".

Sendo assim, cada pessoa será tratada como algo insubstituível. Incumbe ao Estado-juiz, e aos demais sujeitos processuais, garantir respeito à dignidade humana, garantindo "o valor intrínseco de cada vida que é trazida ao processo". Daí se decorre, nas precisas palavras do Professor Alexandre Freitas Câmara, que:

[...] aos sujeitos do processo é preciso sempre ter claro que os titulares dos interesses em conflitos são pessoas reais, cujas vidas serão afetadas pelo resultado do processo e que, por isso mesmo, têm o direito de estabelecer suas estratégias processuais de acordo com aquilo que lhes pareça melhor para suas vidas. É inadmissível tratar as partes como se não fossem pessoas reais, meros dados estatísticos. Afinal, se para o Judiciário cada processo pode parecer apenas mais um processo, para as partes cada processo pode ser o único, o mais relevante, aquele em que sua vida será decidida. E é dever do juiz assegurar que isto seja respeitado. ${ }^{24}$

Ademais, o famigerado artigo $8^{\circ}$. ainda esclarece que na aplicação do direito é necessário que se promova a dignidade da pessoa humana. Há, aqui, verdadeira exigência para que o magistrado tenha um com-

23 CABRAL, Antonio Passo, CRAMER, Ronaldo (orgs.). Comentários ao Novo Código de Processo Civil. Forense, 2015, p. 19.

24 CÂMARA, Alexandre Freitas. O Novo Processo Civil Brasileiro, 2. ed. São Paulo: Atlas, 2016, p. 7. 
portamento ativo, significando, portanto, que, em algumas situações, o juiz poderá tomar, até mesmo de ofício, medidas para efetivar a dignidade da pessoa humana. Didier esclarece que o magistrado, inclusive, poderá "valer-se da cláusula geral de atipicidade (art. 536, § $1^{\circ}$.) para a execução do direito fundamental à dignidade". ${ }^{25}$ Dois exemplos são trazidos pelo mestre baiano, aos quais fazemos questão, a título de ilustração, de transcrevê-los:

a) exigência de respeito à ordem cronológica de conclusão (art. 12); caso de grave violação à dignidade da pessoa humana, que não se encaixe em um dos incisos que excepcionam a regra de observância da cronologia da conclusão; poderia o juiz "furar a fila", para promover a dignidade da pessoa humana; $b$ ) prioridade na tramitação processual; pessoa que seja portadora de doença grave, mas que não esteja no rol do art. 1.048, I; para promover a dignidade de pessoa humana, o juiz poderia determinar o processamento prioritário. ${ }^{26}$

Nesse passo, pode-se dizer que essa dupla garantia - resguardo e promoção - está alinhada ao que a doutrina chama de "dupla eficácia do princípio da dignidade da pessoa humana". ${ }^{27}$ De um lado, tem-se a eficácia negativa: resguardando a pessoa de quaisquer tentativas de coisificação, seja a agressão estatal ou derivada da sociedade, salvaguardando, portanto, a humanidade. De outro lado, tem-se a eficácia positiva, qual seja, a obrigação de fazer que o Estado promova e efetive a dignidade humana.

Vê-se, nessa senda, que o comando normativo é dirigido ao juiz para que ele promova a dignidade da pessoa humana nos casos em que a

25 CABRAL, Antonio Passo, CRAMER, Ronaldo (orgs.). Comentários ao Novo Código de Processo Civil. Forense, 2015, p. 20.

26 IDEM.

27 SARLET, Ingo Wolfgang. Dignidade da pessoa humana e direitos fundamentais na Constituição Federal de 1988. Porto Alegre: Livraria do Advogado, 2001, p. 110. 
perceba ausente e assegure-a quando posta em risco. ${ }^{28}$ É nesse sentido o magistério dos professores Marinoni, Mitidiero e Arenhart, ao comentarem o desiderato da eficácia da dignidade no processo civil:

[...] a dignidade da pessoa humana determina a compreensão do processo civil como um meio para tutela dos direitos. Vale dizer: o processo civil não pode ser visto como um instrumento a serviço do Estado, como um instrumento que não se encontre orientado à realização dos fins da pessoa humana. Em outras palavras, o processo civil serve para realização dos direitos e para orientação das pessoas a respeito do significado do direito. ${ }^{29}$

Em outra direção, não se pode perder de vista que os direitos fundamentais são a concreção efetiva da dignidade da pessoa humana. ${ }^{30}$ Ou seja, não se vislumbra de dignidade humana sem um arcabouço normativo que lhe confira plena eficácia e proteção. É nesse sentido, precisamente, que "os direitos fundamentais são os direitos do ser humano, reconhecidos e positivados na esfera constitucional de determinado Estado, motivando-se numa pretensão geral de respeito e proteção à dignidade da pessoa humana". ${ }^{31}$

Nesse contexto, pode-se afirmar que todos os direitos fundamentais esposados na Constituição Federal, de uma maneira ou de outra, conectam-se ao postulado máximo da dignidade da pessoa humana. Tendo como norte esse ponto de partida, fica fácil asseverar que os

${ }^{28}$ CARMONA, Carlos Alberto et al. O Novo Código de Processo Civil: questões controvertidas. São Paulo: Atlas, 2015, p. 456.

29 MARINONI, Luiz Guilherme; MITIDIERO, Daniel; ARENHART, Sérgio Cruz. Novo Código de Processo Civil comentado, 2. ed. São Paulo: Editora Revista dos Tribunais, 2016, p. 25.

30 HESSE, Konrad. Elementos de direito constitucional da República Federal da Alemanha. Trad. Luís Afonso Heck. Porto Alegre: Sergio Antonio Fabris Editor, 1998, p. 244.

31 BOTELHO, Guilherme. Direito ao processo qualificado: o processo civil na perspectiva do Estado Constitucional. Porto Alegre: Livraria do Advogado, 2010, p. 89. 
direitos e garantias processuais, em última análise, são a concretização da dignidade humana.

Sendo assim, reconhece-se que a aplicação da dignidade da pessoa humana no processo coincide com a aplicação do devido processo legal. ${ }^{32}$ Um processo devido, adequado, eficiente e justo, é um processo que atende à dignidade humana, conferindo tratamento digno às partes e aos demais sujeitos processuais. Partindo dessa noção, no próximo capítulo se analisará detidamente as principais normas estatuídas no novo CPC/2015 que trouxeram guarida ao princípio da dignidade da pessoa humana.

\section{As normas fundamentais do novo Código de Processo Civil que Resguardam e PROTegem a dignidade da Pessoa HUMANA}

A Exposição de Motivos do novo diploma processual deixa claro quais foram os objetivos principais para se transformar e melhorar a prestação jurisdicional: o fortalecimento do contraditório, a maior exigência em termos de fundamentação das decisões, instrumentos voltados para a economia processual, preservação da isonomia, da segurança jurídica e da duração razoável do processo e o maior grau de gestão participativa e democrática, indicam alguns dos propósitos que permearam a feitura do novo CPC.

Tais intuitos revelam a opção do legislador pelo devido processo legal que, conforme já levantado, atendem aos conclames da dignidade da pessoa humana. Dessa forma, pode-se afirmar que todas as cláusulas principiológicas e valorativas contidas no novo Código atendem, numa primeira observação, aos pressupostos constitucionais do processo justo, adequado e efetivo. ${ }^{33}$ Nessa senda, pode-se apontar os artigos $1^{\circ}$. ao

32 CUNHA, Leonardo Carneiro da. Artigo $\mathbf{8}^{\mathbf{0}}$. In: STRECK, Lenio; NUNES, Dierle (orgs.). Comentários ao código de Processo Civil. São Paulo: Saraiva, 2016, p. 46.

33 MARINONI, Luiz Guilherme; MITIDIERO, Daniel; ARENHART, Sérgio Cruz. Novo Código de Processo Civil comentado, 2. ed. São Paulo: Editora Revista dos Tribunais, 2016, p. 28. 
12 - o chamado "Diploma Processual Fundamental" - que estabelecem as primeiras linhas que irão reger o novo Código, daí a nominação de "normas fundamentais do processo civil".

No artigo $3^{\circ}$., por exemplo, tem-se o princípio da inafastabilidade do controle jurisdicional ou, conforme Leonardo Carneiro da Cunha, "princípio do livre acesso à justiça" ${ }^{34}$ Do dispositivo, extrai-se que o acesso à justiça deve ser garantido, a fim de que qualquer cidadão consiga postular seus direitos em juízo, sem qualquer limitação desproporcional. Nesse sentido, não basta o acesso. É importante, ademais, que se viabilize uma solução eficiente, com a implementação de "uma dogmática processual voltada para um processo de resultados concretos". ${ }^{35}$ Aqui, evidentemente, tem-se princípio inaugural de efetividade da dignidade humana, afinal, não se tem como cogitar de um processo devido, adequado e justo, se não tem condições razoáveis de se postular em juízo e de se ter acesso à justiça.

No $\S 2^{\circ}$. do mesmo artigo, tem-se o princípio da solução consensual dos conflitos, ao dispor que "O Estado promoverá, sempre que possível, a solução consensual dos conflitos”. Daí a ideia de existência de um princípio de estímulo da solução por autocomposição. Imbuído desse espírito de cooperativismo processual, o novo CPC congrega um ambiente democrático, cujos pressupostos apontam para a construção de soluções adequadas, com mínimo de lesão à dignidade das partes que postulam em juízo.

A despeito da conciliação, precisamente, o novo estatuto processual procura "infundir a cultura da pacificação entre os protagonistas do processo". ${ }^{36}$ Tem-se, por exemplo, o artigo 165, que prevê a criação de centros judiciários de solução consensual de conflitos, responsáveis

34 CUNHA, Leonardo Carneiro da. Artigo $\mathbf{8}^{\mathbf{0}}$. In: STRECK, Lenio; NUNES, Dierle (orgs.). Comentários ao código de Processo Civil. São Paulo: Saraiva, 2016, p. 47.

35 CUNHA, Leonardo Carneiro da. Artigo $\mathbf{3}^{\mathbf{0}}$. In: . STRECK, Lenio; NUNES, Dierle (orgs.). Comentários ao código de Processo Civil. São Paulo: Saraiva, 2016, p. 32.

36 Disponível em: <http://www.conjur.com.br/2015-out-06/paradoxo-corte-cpc-trazmudancas-audiencia-conciliacao>. Acesso em 10 jun. 2016. 
pelas audiências de conciliação e mediação; o artigo 166, estabelecendo os princípios que informam a conciliação e a mediação; o artigo 319, inc. VII, que faculta ao autor expor na inicial o desejo de participar ou não de audiência conciliatória e o artigo 694, que recomenda, nas controvérsias familiares, a solução consensual, possibilitando, inclusive, a resolução extrajudicial.

Indiscutível, pois que, à luz da dignidade da pessoa humana, um novo horizonte menos beligerante se aproxime do processo civil, pautando-se, inclusivamente, pela gestão participativa e democrática do processo, com a cooperação das partes e a valorização destas em relação aos atos do processo.

Nesse sentido, Nelson Rosenvald diz que a eficácia positiva da dignidade da pessoa humana relaciona-se de forma íntima com o modelo colaboracionista do Estado Democrático, "sendo uma de suas vertentes a materialização da autodeterminação e liberdade de escolha, notadamente vivificada no artigo 190 do CPC/15". ${ }^{37}$ A norma, diz o mestre civilista:

[...] conforma os negócios processuais realizados entre as partes plenamente capazes (...) para fins de mudança de procedimento em direitos que admitam a autocomposição, respeitados os limites do ordenamento quanto a validade desses acordos (v.g. não podem ter por objeto poderes do juiz, renúncia ao núcleo essencial de direitos fundamentais, bem como acordos irrevogáveis ou que envolvam a integralidade do direito). ${ }^{38}$

É no mesmo sentido que Marinoni, Mitidiero e Arenhart se pronunciam, a saber:

37 ROSENVALD, Nelson. A dignidade da pessoa humana no CPC/15. Disponível em: $<$ http://www.nelsonrosenvald.info/\#!A-dignidade-da-pessoa-humana-no-CPC15/c21xn/567465c30cf2c2b7798a7adc >. Acesso em 12 jun. 2016.

38 ROSENVALD, Nelson. A dignidade da pessoa humana no CPC/15. Disponível em: <http://www.nelsonrosenvald.info/\#!A-dignidade-da-pessoa-humana-no-CPC15/c21xn/567465c30cf2c2b7798a7adc>. Acesso em 12 jun. 2016. 
[...] a dignidade da pessoa humana conecta-se com o direito à liberdade e à autonomia privada, o que explica a necessidade de respeito, dentro dos limites constitucionais e legais, aos negócios processuais realizados entre as partes (art. 190, CPC) e constitui estímulo à realização de calendários processuais entre o juiz e as partes como instrumento para eficiente gestão do tempo no processo civil (art. 191, CPC). ${ }^{39}$

No artigo $4^{\circ}$., a seu passo, tem-se que "as partes têm o direito de obter em prazo razoável a solução integral do mérito, incluída a atividade satisfativa". ${ }^{40}$ Numa primeira análise, pode-se dizer que o comando declara a razoável duração do processo. Significa dizer que um processo "somente pode ser qualificado de devido, justo ou équo, se ostentar uma razoável duração". ${ }^{41}$

Dito de outro modo, a solução da causa deve ser obtida em tempo razoável, aí incluída a atividade necessária à satisfação efetiva do direito. Entretanto, não se está defendendo que um processo seja demasiado célere. Um processo que respeita as garantias fundamentais, já nos atenta o Professor Alexandre Freitas Câmara, é, necessariamente, um processo que demora algum tempo. Destarte, "um processo rápido e que não produz resultados constitucionalmente adequados não é eficiente", ${ }^{42}$ o que pode acarretar mácula no devido processo legal e, por consequência, na dignidade das partes que litigam em juízo.

39 MARINONI, Luiz Guilherme; MITIDIERO, Daniel; ARENHART, Sérgio Cruz. Novo Código de Processo Civil comentado, 2. ed. São Paulo: Editora Revista dos Tribunais, 2016, p. 32.

40 No mesmo sentido é o artigo 139, inciso II, reafirmando o compromisso do NCPC: "O juiz dirigirá o processo conforme as disposições deste Código, incumbindo-lhe: velar pela duração razoável do processo".

${ }^{41}$ CUNHA, Leonardo Carneiro da. Artigo $4^{\circ}$. In: . STRECK, Lenio; NUNES, Dierle (orgs.). Comentários ao código de Processo Civil. São Paulo: Saraiva, 2016, p. 35 .

42 CÂMARA, Alexandre Freitas. O Novo Processo Civil Brasileiro, 2. ed. São Paulo: Atlas, 2016, p. 19. 
O mesmo artigo $4^{\circ}$., fazendo-se uma leitura criteriosa, nos revela também o princípio da primazia do julgamento de mérito. Ou seja, as regras processuais devem balizar-se preferencial e prioritariamente pelo primado da análise ou do julgamento de mérito. Nesse sentido, “o processo é um método de resolução do caso concreto, e não um mecanismo destinado a impedir que o caso concreto seja solucionado". ${ }^{43} \mathrm{O}$ juiz, a fim de conferir eficácia ao mandamento legal, toda vez que possível, deve superar os vícios, estimulando e permitindo sua correção, a fim de que possa efetivamente debruçar-se sobre o mérito e solucionar o conflito entre as partes. ${ }^{44}$

Nesse contexto, evidentemente, o Poder Judiciário há de estar atento a tais mudanças, de modo a compatibilizar a teoria processual com a prática judicante efetiva. A despeito, inclusive, o Professor Elias Marques de Medeiros Neto proclama que:

Para a obtenção da efetiva prestação da tutela jurisdicional - aqui entendida como a tutela pautada pelos princípios da eficiência, da duração razoável do processo, da celeridade, do devido processo legal e inspirada nos sólidos fundamentos do pleno acesso à justiça -, dois grandes desafios devem ser enfrentados.

O primeiro, de natureza institucional, implica a importância de o Estado se aparelhar de forma apta a gerir eficazmente as resoluções de conflitos; de nada adianta uma legislação processual ultramoderna se o Estado, por intermédio dos seus órgãos - entre os quais o Poder Judiciário -, não está apto a dirimir de forma efetiva as lides.

[...]

O segundo desafio passa pela necessidade de a legislação processual conferir os mecanismos necessários para que o titular do direito material possa receber uma

43 IDEM.

44 Com o mesmo objetivo do preceito do artigo $4^{\circ}$., tem-se o $\S 2^{\circ}$. do artigo 282: "quando puder decidir o mérito a favor da parte a quem aproveite a decretação da nulidade, o juiz não a pronunciará nem mandará repetir o ato ou suprir-lhe a falta". 
resposta adequada, oportuna, tempestiva e eficaz do Poder Judiciário, uma legislação processual adaptada às especificidades dos diferentes casos concretos que são levados diariamente ao conhecimento do Poder Judiciário, e que realmente possibilite ao demandante obter as garantias necessárias para a concreta realização do seu direito.

Os dois desafios devem e precisam ser enfrentados, sendo ambos fundamentais para a obtenção da almejada efetividade do processo. ${ }^{45}$

Seguindo os preceitos iniciais do Novo CPC que tangenciam a dignidade da pessoa humana, tem-se ainda o princípio da boa-fé objetiva amarrado no artigo $5^{\circ}$., in verbis: "Aquele que de qualquer forma participa do processo deve comportar-se de acordo com a boa-fé".

A boa-fé, não se descuida, já era prevista no Código revogado como um dos deveres das partes e de seus procuradores. No novo Código, entretanto, a boa-fé é erigida à categoria de norma fundamental do Processo Civil, tendo efeito irradiante em relação às demais normas do ordenamento processual. ${ }^{46}$ Nelson Rosenvald, ${ }^{47}$ inclusive, compreende que o fundamento constitucional da boa-fé objetiva decorre da proteção à dignidade da pessoa humana, conferida pelo artigo $1^{\circ}$., III, da CF.

Com efeito, a boa-fé objetiva é elemento que deve ser levado em conta "necessariamente na interpretação dos atos jurídicos em geral e inclusive - nem poderia ser diferente - dos atos processuais". ${ }^{48} \mathrm{Nessa}$ direção, o CPC de 2015 faz uso dessa vertente da dignidade humana

45 MEDEIROS NETO, Elias Marques de. O artigo $4^{\circ}$. do novo Código de Processo Civil e o princípio da efetividade do processo. In: Reflexões sobre o novo Código de Processo Civil Orgs. Geisa de Assis Rodrigues, Robério Nunes dos Anjos Filho. Brasília: ESMPU, 2016, v. 1, p. 253-254.

46 Jr., MACHADO, Dario Ribeiro, CARNEIRO, Paulo Pinheiro, PINHO, Humberto Dalla de. Novo Código de Processo Civil - Anotado e Comparado. Rio de Janeiro: Forense, 2015, p. 17.

47 ROSENVALD, Nelson. Dignidade humana e boa-fé no Código Civil. São Paulo: Saraiva, 2005, p. 186 e s.

48 BUENO, Cassio Scarpinella. Manual de Direito Processual Civil: inteiramente estruturado à luz do novo CPC. São Paulo: Saraiva, 2015, p. 83. 
em dois momentos. O primeiro está no $\S 2^{\circ}$. do artigo 322 sobre a interpretação do pedido formulado pelo autor quando ingressa em juízo: "A interpretação do pedido considerará o conjunto da postulação e observará o princípio da boa-fé". De outro lado, o $§ 3^{\circ}$. do artigo 489, na oportunidade da interpretação das decisões judiciais, é expresso no sentido de que "a decisão judicial deve ser interpretada a partir da conjugação de todos os seus elementos e em conformidade com o princípio da boa-fé".

Destarte, a cláusula geral do artigo $5^{\circ}$. do novo diploma processual é, nos dizeres de Fredie Didier Jr:

[...] a fonte normativa da proibição do exercício inadmissível de posições jurídicas processuais, que podem ser reunidas sob a rubrica do "abuso do direito" processual (desrespeito à boa-fé objetiva). Além disso, o princípio da boa-fé processual torna ilícitas as condutas processuais animadas pela má-fé (sem boa-fé subjetiva). Ou seja, a boa-fé objetiva processual implica, entre outros efeitos, o dever de o sujeito processual não atuar imbuído de má-fé, considerada como fato que compõe o suporte fático de alguns ilícitos processuais. ${ }^{49}$

Sendo assim, dúvidas inexistem que a incidência da boa-fé impõe aos agentes do Poder Judiciário, e também às partes envolvidas na celeuma jurisdicional, um dever de agir segundo os comportamentos socialmente assentados na tradição da lisura, coerência e lealdade. A boa-fé objetiva, portanto, acaba por funcionar como vetor da dignidade humana nas relações entre todos os sujeitos processuais.

Não obstante o dever de lealdade e lisura exposto no artigo $5^{\circ}$., o novo Código de Processo Civil ainda prescreve no artigo $6^{\circ}$. que "todos os sujeitos do processo devem cooperar entre si para que se obtenha, em tempo razoável, decisão de mérito justa e efetiva". O cooperativismo processual deriva, consoante o magistério de Leonardo Carneiro da

49 CABRAL, Antonio Passo, CRAMER, Ronaldo (orgs.). Comentários ao Novo Código de Processo Civil. Forense, 2015, p. 27. 
Cunha, da sobredita boa-fé objetiva. $\mathrm{O}$ artigo $6^{\circ}$., pois, é um corolário do artigo $5^{\circ} .^{50}$

Tal preceito ainda congrega os valores do contraditório e do devido processo legal, uma vez que às partes é conferida oportunidade de participarem no convencimento do juiz. Instaurando-se, pois, um novo modelo de processo pautado no princípio da cooperação. Tal modelo cooperativo:

[...] afasta-se da ideia liberal do processo, que tem um juiz passivo, responsável por arbitrar uma 'luta' ou 'guerra' entre as partes. O modelo cooperativo também se afasta da ideia de um processo autoritário, em que o juiz tem uma postura solipsista, com amplos poderes. ${ }^{51}$

É nessa direção que se pode afirmar que, em sua perspectiva mais ampla, o contraditório é a garantia de participação das partes no processo, aí incluída a possibilidade de influir - legitimamente no convencimento do juiz, o que reforça a estrutura marcadamente dialética do processo e a convicção de que, quanto mais diálogo houver, tanto melhor será o resultado da tutela jurisdicional pleiteada.

Nesse passo, pois, a figura do juiz torna-se importantíssima, vez que esse modelo o qualifica como um dos participantes do processo, igualmente gravado pela necessidade de observar o contraditório ao longo de todo o procedimento e, nessa linha, esse juiz estaria "obrigado ao debate, ao diálogo judiciário", estando gravado, em certa medida, por "deveres de esclarecimento, prevenção, consulta e auxílio para com os litigantes". ${ }^{52}$

Assim, no processo guiado pela colaboração, as partes e o juiz ficam em plano de igualdade, com intenso diálogo sobre os rumos do processo em verdadeiro passo de modelo cooperativo.

50 CUNHA, Leonardo Carneiro da. Artigo $6^{\circ}$. In: . STRECK, Lenio; NUNES, Dierle (orgs.). Comentários ao código de Processo Civil. São Paulo: Saraiva, 2016, p. 41 .

51 IBIDEM, p. 43.

52 MITIDIERO, Daniel. Colaboração no processo civil: pressupostos sociais, lógicos e éticos, 2. ed. São Paulo: Revista dos Tribunais, 2011, esp. p. 84. 
O juiz do processo dito cooperativo deve ser, nos aclara Daniel Mitidiero: ${ }^{53}$

[...] um juiz isonômico na condução do processo e assimétrico no quando da decisão das questões processuais e materiais da causa. Desempenha duplo papel, pois, ocupa dupla posição; paritário no diálogo, assimétrico na decisão. Visa-se alcançar, com isso, um ponto de equilíbrio.

É de se ressaltar, portanto, que o princípio da cooperação impõe e "orienta o magistrado a tomar uma decisão de agente-colaborador do processo, de participante ativo do contraditório e não mais de um mero fiscal de regras". ${ }^{54} \mathrm{O}$ princípio da cooperação parte, com razão, da necessidade de o juiz adotar uma postura de diálogo com as partes e os demais sujeitos do processo. ${ }^{55}$

Ainda, conforme Fredie Didier Júnior, o princípio da colaboração gera os seguintes deveres para o magistrado: i) dever de esclarecimento; ii) dever de consultar; iii) dever de prevenir; e iv) dever de auxiliar.

Pelo dever de esclarecimento, o juiz deve esclarecer-se junto às partes quanto às dúvidas que tenha sobre as suas alegações, pedidos ou posições em juízo. O dever de consultar está ligado ao direito ao contraditório, devendo o juiz consultar as partes sobre as questões de fato ou de direito, antes de decidir a lide. O dever de prevenir, por sua vez, "vale genericamente para todas as situações em que o êxito da ação possa ser frustrado pelo uso inadequado do processo". ${ }^{56} \mathrm{O}$ dever de auxiliar se materializa nos esclarecimentos necessários às partes, bem como, na diretriz de que o magistrado deve zelar primordialmente pela solução do conflito, evitando-se desnecessárias extinções da lide sem a apreciação do mérito.

Ademais, o novo CPC em seu artigo $7^{\circ}$. congrega e densifica o devido processo legal nos seguintes termos: "É assegurada às partes paridade

${ }^{53}$ MITIDIERO, op. cit., p. 81.

${ }_{54}$ DIDIER JR., Fredie. Curso de direito processual civil. Teoria geral do processo e processo de conhecimento, 6. ed. Salvador: JusPodivm, 2006, v. 1, p. 71.

55 IDEM, IBIDEM.

${ }^{56}$ DIDIER JR., Fredie. Op. cit. p. 74. 
de tratamento em relação ao exercício de direitos e faculdades processuais, aos meios de defesa, aos ônus, aos deveres e à aplicação de sanções processuais, competindo ao juiz zelar pelo efetivo contraditório".

O dispositivo revela duas diretrizes. A primeira, esposada na consagração do princípio da igualdade no processo, assegurando às partes paridade de tratamento. A segunda, impõe um dever ao juiz, qual seja, zelar pelo efetivo contraditório, reequilibrando as eventuais desigualdades existentes no processo. O princípio do contraditório, tal qual disciplinado no novo CPC, revela uma dupla garantia: a de participação com influência no resultado decisório e a vedação de não surpresa.

Na primeira acepção, tem-se que "o resultado do processo deve ser fruto de intenso debate e da efetiva participação dos interessados, não podendo ser produzido de forma solitária pelo juiz". ${ }^{57}$ Nesse sentido, qualquer fundamento de decisão precisa ser submetido ao crivo do contraditório, assegurando-se oportunidade para que as partes se manifestem especificamente sobre qualquer fundamento decisório. Não é por outro motivo que, nos termos do artigo 10, "o juiz não pode decidir, em grau algum de jurisdição, com base em fundamento a respeito do qual não se tenha dado às partes oportunidade de se manifestar, ainda que se trate de matéria sobre a qual deva decidir de ofício".

Vê-se, portanto, que o modelo de processo cooperativo, comparticipativo, moldou o Código de Processo Civil, de modo que o devido processo legal lastreia-se, sobretudo, com respeito a um contraditório prévio, efetivo e dinâmico. Não é por outra razão, conforme Câmara, que o artigo $9^{\circ}$. expressamente dispõe que "não se proferirá decisão contra uma das partes sem que ela seja previamente ouvida”. Trata-se de verdadeira garantia processual que norteia o resguardo e a promoção da dignidade da pessoa humana no trato do processo.

Todos esses preceitos normativos, induvidosamente, revelam a constitucionalização efetiva do direito processual civil, com o respeito na legislação infraconstitucional aos princípios da isonomia, do devido

57 CÂMARA, Alexandre Freitas. O Novo Processo Civil Brasileiro, 2. ed. São Paulo: Atlas, 2016, p. 11. 
processo legal, do contraditório e da ampla defesa. Todos esses indissociáveis do princípio da dignidade da pessoa humana.

Ademais, pragmaticamente, se poderia pensar em quais hipóteses a dignidade humana foi protegida - além das já sustentadas - no CPC/2015. Leonardo Carneiro da Cunha exemplifica alguns comandos normativos que privilegiam a humanização do processo, a saber:

[...] o disposto no art. 199, que assegura às pessoas com deficiência a acessibilidade aos meios eletrônicos de comunicação processual e aos sítios na rede mundial de computadores; de igual modo, a proibição de perguntas vexatórias à testemunha (CPC, art. 459, § 2.o); bem como a impenhorabilidade de alguns bens (CPC, art. 833); e, bem ainda, a tramitação prioritária de processos que tenham como parte ou interveniente pessoa idosa ou portadora de doença grave (CPC, art. 1.048, I). Além desses e de outros exemplos aqui não citados, as hipóteses previstas no art. 244 do CPC, que vedam a citação nas situações ali indicadas, destinam-se a resguardar a dignidade humana. ${ }^{58}$

Tais preceitos, induvidosamente, concretizam o princípio da dignidade da pessoa humana no processo civil. O artigo 199, por exemplo, implementa a ideia de que é dever do Poder Público implementar políticas de acesso aos bens da vida àquelas pessoas que porventura não possuam igualdade de condições em relação aos demais. Vê-se, pois, que o artigo 199 estabelece importante "política de inclusão" processual. Ao comentar a excelente inovação, Alexandre Freire Pimentel relembra que o novo CPC "apresenta-se como o primeiro ato legislativo brasileiro, entre os que dispuseram sobre processo eletrônico, que demonstrou atenção às pessoas com necessidades especiais". ${ }^{59}$ Antes,

58 CUNHA, Leonardo Carneiro da. Artigo 8 . In: __. STRECK, Lenio; NUNES, Dierle (orgs.). Comentários ao código de Processo Civil. São Paulo: Saraiva, 2016, p. 47.

59 PIMENTEL, Alexandre Freire. In: STRECK, Lenio Luiz; CUNHA, Leonardo Carneiro da; NUNES, Dierle (orgs.). Comentários ao código de Processo Civil. São Paulo: Saraiva, 2016, p. 317. 
apenas o Conselho Nacional de Justiça havia acordado para esse dever de cidadania e promoção da dignidade no processo.

O parágrafo segundo do artigo 459, de outro lado, estabelece que "as testemunhas devem ser tratadas com urbanidade, não se lhes fazendo perguntas ou considerações impertinentes, capciosas ou vexatórias". Aqui, também, tem-se o resguardo da dignidade de sujeitos que participam colaborando da resolução do litígio.

$\mathrm{O}$ artigo 833, a seu turno, estabelece a ideia de que "a execução não pode ser utilizada como instrumento para causar a ruína, a fome e o desabrigo do devedor e sua família, gerando situações incompatíveis com a dignidade da pessoa humana". ${ }^{60}$ É nessa direção, especificamente, que o novo preceito do CPC enumera vários casos de bens patrimoniais disponíveis que são impenhoráveis, como os vestuários e pertences de uso pessoal, os vencimentos e salários, os livros, máquinas, utensílios e ferramentas necessários ao exercício da profissão, as pensões, o seguro de vida etc.

A impenhorabilidade de certos bens, nesse caso:

[...] É uma restrição ao direito fundamental à tutela executiva. É técnica processual que limita a atividade executiva e que se justifica como meio de proteção de alguns bens jurídicos relevantes, como a dignidade do executado, o direito ao patrimônio mínimo e a função social da empresa. ${ }^{61}$

Sobre o tema, inclusive, sabe-se que as regras relativas às medidas executivas recomendam uma interpretação à luz da Constituição Federal, vez que se voltam à realização de direitos fundamentais e, em sua realização, podem atingir direitos fundamentais. ${ }^{62}$ Sob essa perspectiva, adicionalmente, já se decidiu que:

${ }_{60}$ THEODORO JÚNIOR, Humberto. Novo Código de Processo Civil Anotado, 20. ed. Rio de Janeiro: Forense, 2016, p. 978.

${ }^{61}$ DIDIER JR., Fredie; CUNHA, Leonardo Carneiro da; BRAGA, Paula Sarno; OLIVEIRA, Rafael Alexandria de. Curso de direito processual civil, 3. ed. Salvador: JusPodivm, 2011, v. 5, p. 547.

62 MEDINA, José Miguel Garcia. Novo Código de Processo Civil comentado, 1. ed. São Paulo: Editora Revista dos Tribunais, 2015, p. 736. 
O rol das impenhorabilidades do ordenamento pátrio objetiva preservar o mínimo patrimonial necessário à existência digna do executado, impondo ao processo executório certos limites. Assim, a depender das peculiaridades do caso, as regras de impenhorabilidade podem ser ampliadas, de modo a adequar a tutela aos direitos fundamentais, como por exemplo: o direito à moradia, à saúde ou à dignidade da pessoa humana. Trata-se, portanto, da aplicação do princípio da adequação e da necessidade sob o enfoque da proporcionalidade (STJ, REsp 1.436.739/PR, rel. Min. Humberto Martins, 2. ${ }^{\mathrm{a}}$ T., j. 27.03.2014).

É diante, portanto, da expressa submissão que há no Código de Processo Civil aos ditames constitucionais, conforme se depreende do artigo $1^{\circ}$. da codificação, que se pode afirmar que a análise de questões que envolvem a penhorabilidade de bens terá núcleo básico fincado na conjunção dos princípios constitucionais da dignidade da pessoa humana (art. $1^{\circ}$., III, da CF) e da função social da propriedade (art. $5^{\circ}$., XXIII, da CF).

Assim, firmada nessas premissas, a interpretação dos dispositivos que tratam da penhora no CPC2015 não pode se distanciar de matrizes constitucionais, especialmente as já referidas, de modo que tanto em relação ao devedor, quanto em relação ao credor - em respeito ao tratamento isonômico pregado no ordenamento jurídico - o intérprete deve privilegiar a opção mais em sintonia com a Carta Constitucional.

Não obstante, o artigo 833 do CPC traz uma série de incisos que apontam quais bens são impenhoráveis. Vejamos, brevemente, cada um deles, tendo em vista a importância de que se reveste tal instituto.

A primeira hipótese de impenhorabilidade, prevista no inciso I do artigo 833, abrange os bens inalienáveis e aqueles declarados, por ato voluntário, não sujeitos à execução. São inalienáveis, por exemplo, os bens públicos, regra geral, bem, como os direitos de natureza personalíssima, como é o caso do usufruto.

O inciso II, por sua vez, a exemplo da previsão do artigo $1^{\circ}$., parágrafo único, e artigo $2^{\circ}$. da Lei 8.009/90, estabelece que também são 
impenhoráveis, via de regra, os bens móveis, os pertences e as utilidades domésticas da residência do executado, como móveis, eletrodomésticos, eletroportáteis etc. Nessa regra, todavia, excepcionam-se os bens dessa natureza que sejam de elevado valor ou que ultrapassem as necessidades comuns correspondentes a um médio padrão de vida. Conceitos estes, evidentemente, deveras indeterminados, de modo que seus contornos vêm sendo fixados casuisticamente pela jurisprudência. A despeito, o Professor Misael Montenegro Filho esclarece que:

Embora a jurisprudência não tenha pacificado o assunto, o que não permite a apresentação de relação dos bens que podem ser atingidos pela penhora (embora guarneçam a residência do executado), anotamos que, com frequência, os tribunais permitem o aperfeiçoamento da penhora dos seguintes bens: (a) de tapetes de alto valor (como persas); (b) de quadros; (c) de televisores e de outros aparelhos eletrônicos e eletrodomésticos em repetição, sobretudo televisores de grandes telas e de plasma; (d) de home theater e de aparelhos similares. ${ }^{63}$

Na mesma direção, o inciso III estabelece a impenhorabilidade de vestuários e pertences de uso pessoal do executado, como roupas, celular, relógio, calçados, salvo se de elevado valor.

Seguindo-se os incisos do artigo 833, chega-se, talvez, ao mais importante. O inciso IV resguarda de execução os vencimentos, os subsídios, os soldos, os salários, as remunerações, os proventos de aposentadoria, as pensões, os pecúlios e os montepios, quantias recebidas de terceiro e destinadas ao sustento do devedor e de sua família, os ganhos de trabalhador autônomo e os honorários de profissional liberal, salvo na hipótese de execução de prestação alimentícia.

Tal impenhorabilidade, não obstante as severas críticas que lhe acompanha, é louvável, vez que atende ao princípio da dignidade da pessoa humana, em especial em razão do seu caráter primordialmente

63 MONTENEGRO Filho, Misael. Novo Código de Processo Civil Comentado, 2. ed. São Paulo: Editora Atlas, 2016, p. 748. 
alimentar, tendo em vista que garante o sustento do executado e de sua família, bem como, o acesso a itens de primeira necessidade. Todavia, a exceção à regra da responsabilidade patrimonial não é todo extensa, vez que, em boa hora, o parágrafo segundo do artigo 833 limitou a extensão da impenhorabilidade a cinquenta salários mínimos. Assim, os valores que excederem tal montante poderão ser penhorados e utilizados para a satisfação da execução.

Na quinta hipótese resguardada de execução tem-se os livros, as máquinas, as ferramentas, os utensílios, os instrumentos ou outros bens móveis necessários ou úteis ao exercício da profissão do executado. Incluem-se, ainda, nessa hipótese de impenhorabilidade, por força do $\S$ $3^{\circ}$. do artigo 833, os equipamentos, implementos e máquinas agrícolas pertencentes a pessoa física ou a empresa individual produtora rural.

Referida proteção, nos esclarece Rodrigo Mazzei e Sarah Merçon-Vargas: ${ }^{64}$

Tem assento na noção de que a dignidade estende-se também ao exercício da profissão, em si mesma e também por representar a forma, por excelência, de que dispõe o executado para continuar a receber sua remuneração e, por conseguinte, prover seu sustento e de sua família. Trata-se, também, de aplicação pontual da função social da propriedade, já que protege os bens que permitem a circulação de riquezas para a subsistência do executado e, se for o caso, de sua família.

Entretanto, excluem-se da proteção legal os bens que sejam supérfluos, voluptuários, não essenciais à continuidade da atividade profissional do devedor.

Importante observar ainda que a impenhorabilidade do inc. $\mathrm{V}$ alcança apenas os bens móveis, de modo que é absolutamente possível que o imóvel em que o executado exerça sua atividade profissional seja penhorado, conforme a Súmula 451 do STJ: "É legítima a penhora da sede do estabelecimento comercial".

${ }^{64}$ CABRAL, Antonio Passo, CRAMER, Ronaldo (orgs.). Comentários ao Novo Código de Processo Civil. Rio de Janeiro: Forense, 2015, p. 1.194. 
A sexta hipótese de impenhorabilidade trata do seguro de vida. A melhor interpretação doutrinária, que protege e promove a dignidade da pessoa humana, aponta que o dispositivo resguarda de execução o capital recebido como benefício de seguro de vida de terceiro, estipulado em favor do executado, não podendo, portanto, ser alvo de penhora.

Pela regra do inciso VII do artigo 833 do novo Diploma Processual, por sua vez, são também impenhoráveis os materiais necessários para a conclusão de obras em andamento, salvo se estas forem penhoradas. O inciso VIII, por seu turno, estabelece a impenhorabilidade da pequena propriedade rural, tal como definida em lei, desde que trabalhada pela família. A proteção legal é mais ampla do que a garantia prevista no artigo $5^{\circ}$., XXVI, da CF, pois a impenhorabilidade não se limita às execuções de débitos decorrentes de sua atividade produtiva, podendo ser alegada em toda e qualquer execução.

A nona hipótese de impenhorabilidade compreende os recursos públicos recebidos por instituições privadas para aplicação compulsória em educação, saúde ou assistência social. A proteção é louvável e tutela toda a coletividade, ao privilegiar o direito à educação, saúde e assistência social em detrimento do direito do credor.

$\mathrm{O}$ inciso X, por sua vez, estabelece a impenhorabilidade da quantia depositada em caderneta de poupança, até o limite de quarenta salários mínimos. Além da proteção prevista no inciso IV, que põe a remuneração do executado a salvo de execução, o legislador resguardou a sua poupança até o valor de quarenta salários mínimos. De fato, entre os bens considerados essenciais à vida digna, que não podem ser constritos em execução, está a reserva que se faz por segurança para momentos de desemprego, crise ou contingências imprevistas.

O critério utilizado pelo legislador, nesse caso, é o do valor global depositado em poupança(s). Nesse sentido, o STJ já decidiu que “é impenhorável a quantia de até quarenta salários-mínimos do total depositado em todas as cadernetas de poupança devidamente somadas" (STJ, REsp 1.231.123/SP, 3. T., rel. Min. Nancy Andrighi, j. 02.08.2012, DJe 30.08.2012). 
Em outro giro, são também impenhoráveis, por força do inciso XI, os recursos públicos do fundo partidário recebidos por partido político, nos termos da lei. Tal regra busca garantir, em certa medida, o pluralismo político que rege a nossa República.

Com efeito, a grande novidade desse artigo 833 é a impenhorabilidade dos créditos de alienação de unidades imobiliárias (inc. XII), sob regime de incorporação, vinculados à execução da obra. A regra tem por objetivo evitar que dívidas do incorporador possam consumir os recursos que seriam utilizados na realização da obra, em prejuízo dos adquirentes de unidades autônomas. A despeito, comentando a novidade processual, colhe-se a lição do Professor Misael Montenegro Filho, ${ }^{65}$ para o qual:

Ao estabelecer a impenhorabilidade dos créditos oriundos de alienação de unidades imobiliárias, o novo CPC protegeu os valores destinados à execução da obra e à entrega das unidades imobiliárias aos adquirentes, assegurando, assim, a execução da promessa contratual.

Vê-se, diante de todo o plexo protetivo do artigo 833, que as hipóteses de impenhorabilidade são consentâneas com o princípio da dignidade da pessoa humana. Todavia, tais cláusulas não tendem a serem absolutas. Ao contrário: a sua relativização, a depender do caso sob exame, deve ser realçada, à medida que a dignidade resguardada e protegida pelo sistema processual-constitucional não se limita ao executado. É premente, advertidamente, que a dignidade do credor também seja garantida em juízo, tendo como norte, pois, os princípios da proporcionalidade e razoabilidade.

Sem embargo, a cláusula do artigo 805 do Código de Processo de Civil de 2015 torna-se paradigma para o processo de execução. Vejamos o seu teor:

65 MONTENEGRO Filho, Misael. Novo Código de Processo Civil Comentado, 2. ed. São Paulo: Editora Atlas, 2016, p. 752. 
Artigo 805. Quando por vários meios o exequente puder promover a execução, o juiz mandará que se faça pelo modo menos gravoso para o executado.

Parágrafo único. Ao executado que alegar ser a medida executiva mais gravosa incumbe indicar outros meios mais eficazes e menos onerosos, sob pena de manutenção dos atos executivos já determinados.

Tal preceito estabelece o que a doutrina processual convencionou chamar de "princípio da menor onerosidade para o executado". Também conhecido como "princípio do menor sacrifício possível do executado", sua premissa reside na ideia de que a execução civil se volta à satisfação do direito do credor e não à punição do devedor.

Nesse sentido, os atos judiciais devem se restringir exclusivamente ao indispensável para alcançar o cumprimento da obrigação certificada, de modo que o juiz deve atentar-se para que a execução se faça pelo modo menos gravoso para o executado, quando, por vários meios, o credor puder promovê-la. Vê-se, de pronto, que a teleologia da norma em comento inspira-se nos princípios da justiça e da equidade.

Entretanto, a menor onerosidade não pode servir de motivo para a execução ser frustrada. Deve-se, a contrario sensu, balancear-se para que a execução seja o mais eficiente possível para o credor e com o menor sacrifício possível para o devedor. A despeito, Antonio Adonias Aguiar Bastos ${ }^{66}$ esclarece que:

\begin{abstract}
Se, de um lado, o princípio da efetividade da execução forçada é considerado como um direito fundamental à execução equilibrada sob a perspectiva do exequente, de outro lado, o princípio da menor onerosidade complementa o conceito, enquanto direito fundamental à execução equilibrada sob o prisma do executado. A execução balanceada é, portanto, aquela que propicia o pleno atendimento do direito do exequente sem sacrificar inutilmente o patrimônio do executado.
\end{abstract}

66 CABRAL, Antonio Passo, CRAMER, Ronaldo (orgs.). Comentários ao Novo Código de Processo Civil. Forense, 2015, p. 798. 
No mesmo sentido é a inteligência, sempre didática, do Professor Elpídio Donizzeti, ${ }^{67}$ para o qual:

\begin{abstract}
Esse princípio tem, contudo, que ser aplicado harmonicamente com o princípio da efetividade da execução, já que a finalidade do processo executivo é a satisfação do credor, e não o contrário.

Em outras palavras, o princípio da menor onerosidade deve atuar como uma espécie de freio ou limite à satisfação do credor, de forma a impedir que direitos patrimoniais assolem direitos de maior significância, como é o caso da dignidade da pessoa humana (art. 1o, III, da CF). Há, porém, um limite também ao princípio da menor onerosidade, cuja incidência não pode servir de amparo a calotes de maus pagadores.
\end{abstract}

A jurisprudência, inclusive, ainda na égide no CPC de 1973, consolidando o referido princípio, já se pronunciava no sentido de que ele:

[...] expressa típica regra de sobre direito, cuja função é a de orientar a aplicação das demais normas do processo de execução, a fim de evitar a prática de atos executivos desnecessariamente onerosos ao executado. Embora não tenha força para, por si só, comprometer a ordem legal da nomeação e substituição dos bens à penhora estabelecida no artigo 655 do Código de Processo Civil, o princípio da menor onerosidade (art. 620 do CPC) pode, em determinadas situações específicas, ser invocado para relativizar seu rigorismo, amoldando-o às peculiaridades do caso concreto (STJ, REsp 725.587/PR, Rel. Min. Teori Albino Zavascki, $1^{\text {a }}$ Turma, jul. 13.09.2005, DJ 26.09.2005).

Vê-se, pois, que na aplicação do princípio da menor onerosidade,

${ }^{67}$ DONIZETTI, Elpídio. Novo código de processo civil comentado (Lei no ${ }^{\circ}$ 13.105, de 16 de março de 2015): análise comparativa entre o novo CPC e o CPC/73. São Paulo: Atlas, 2015, p. 831. 
o magistrado deve se valer do princípio da proporcionalidade no caso concreto, de modo a evitar que ele se constitua numa espécie perigosa de escudo a impedir a satisfação da obrigação. Seu substrato, entretanto, serve como garantia de que, diante da verificação da existência de mais uma possibilidade para a satisfação do crédito, o juiz deverá escolher a menos gravosa para o devedor:

É certo que o princípio da menor onerosidade não pode ser analisado isoladamente. Ao lado dele, há outros princípios informativos do processo de execução, dentre eles, o da máxima utilidade da execução, que visa à plena satisfação do exequente. Cumpre, portanto, encontrar um equilíbrio entre essas forças, aplicando-se o princípio da proporcionalidade, com vistas a buscar uma execução equilibrada, proporcional. ${ }^{68}$

Inobstante, a novidade prevista no parágrafo único do artigo 805 pretende evitar a arguição genérica e sem fundamento do princípio da menor onerosidade para o devedor. Assim, com o acréscimo do parágrafo em exame, o executado deverá informar que outra medida pode ser adotada pelo magistrado no lugar do ato oneroso praticado. O ônus, portanto, de indicar outros meios mais eficazes e menos onerosos é do executado.

Tal preceito, inclusive, fortalece e prestigia a boa-fé entre as partes (art. $5^{\circ}$. do CPC). Nesse sentido, é o magistério de Leonardo Carneiro da Cunha: ${ }^{69}$

O princípio da menor onerosidade tem por finalidade proteger a boa-fé, ao impedir o abuso do direito pelo credor que, sem qualquer vantagem, opta pelo meio executivo mais oneroso ao executado. Não se trata de

${ }^{68}$ WAMBIER, Teresa Arruda Alvim. Primeiros comentários ao novo código de processo civil. São Paulo: Editora Revista dos Tribunais, 2016, artigo 805.

${ }^{69}$ CUNHA, Leonardo Carneiro da. Artigo 805. In: STRECK, Lenio; NUNES, Dierle (orgs.). Comentários ao código de Processo Civil. São Paulo: Saraiva, 2016, p. 1.061. 
princípio que sirva para resguardar a dignidade do executado, já protegida pelas regras que limitam os meios executivos, sobretudo as que preveem as impenhorabilidades. O princípio protege a lealdade processual, servindo para a construção de regras que inibam ou impeçam o comportamento abusivo do exequente.

Densificando tal principiologia, pode-se apontar, ainda no processo de execução, o artigo 847 do Código de Processo Civil. O dispositivo disciplina as hipóteses em que o executado pode pleitear a substituição do bem penhorado. Com a referida regra, a lei processual preserva o ônus, conforme adiantado, para o executado mostrar que a substituição levada a cabo não trará prejuízo para o credor e, simultaneamente, lhe será menos gravosa. Trata-se, de acordo com o Professor Cassio Scarpinella Bueno, de "um caso claro de concretização do princípio agasalhador no parágrafo único do art. 805 e que encontra eco também no parágrafo segundo do art. $829 "{ }^{70}$

O direito à alteração do bem penhorado, nos precisos termos do artigo em comento, é condicionado a dois requisitos: o primeiro de ordem temporal, consistente no prazo de dez dias da intimação da penhora, sob pena de preclusão, e o segundo de ordem formal, que é a exigência de perfeita individuação do bem substituto, de modo a se evidenciar o seu atendimento aos objetivos da execução.

Todas as alterações visam reforçar, em certa medida, a efetividade do processo executório e têm por fundamento basilar o dever das partes de colaborar com o Poder Judiciário. Nessa direção, portanto, o executado tem o dever de além de atribuir valor aos indicados à penhora, como já previa o CPC de 1973, especificar os ônus e possíveis encargos a que estejam sujeitos.

Ademais, privilegiando o princípio do contraditório, inclui-se no mesmo dispositivo o direito de o exequente ter ciência do requerimento do executado e de se manifestar no prazo de três dias (art. 853 do

70 BUENO, Cassio Scarpinella. Manual de processo civil: baseado no novo código de processo civil, 1. ed. São Paulo: Saraiva, 2015, p. 656. 
CPC2015) sobre o pedido de substituição do bem penhorado. Tal regra evidencia a garantia de não surpresa, consectário de um processo jurisdicional democrático. A despeito, Misael Montenegro Filho comenta que:

O magistrado não pode deferir o pedido de substituição sem antes conceder vista dos autos ao exequente, em respeito ao princípio do contraditório e da ampla defesa (inciso LV do art. $5^{\circ}$. da CF), sob pena de nulidade do pronunciamento, exceto se o prejuízo não for demonstrado. ${ }^{71}$

Além desses preceitos, pode-se ainda enunciar como postulados de um processo jurisdicional que atente para a dignidade da pessoa humana os artigos 1.048, I, o 244, o 404 e o artigo 139, I, do CPC de 2015.

No primeiro, garante-se a prioridade processual para aqueles que, como parte ou interessado, tenham idade igual ou superior a 60 (sessenta) anos ou sejam portadores de doença grave. De inovador, no tocante aos beneficiários da tramitação prioritária, pode-se apontar a referência ao dispositivo da Lei n. 7.713/88, que defere isenção do imposto de renda, por doença, a pessoas físicas que portam moléstias nas situações ali numeradas. Vê-se, precisamente, que o Novo CPC aumenta o leque de casos em que a prioridade processual será alcançada, não se evidenciando, entretanto, que o código tenha criado um rol taxativo, com exclusão da possibilidade de extensão do benefício a outros casos. $\mathrm{O}$ magistrado, a fim de resguardar e promover a dignidade humana, nos termos do artigo $8^{\circ}$. da Lei $13.105 / 2015$, poderá estender a prioridade para situações em que fique evidenciada a urgência na tramitação.

Em outro giro, o artigo 244 estatui que:

Artigo 244. Não se fará a citação, salvo para evitar o perecimento do direito:

I - de quem estiver participando de ato de culto religioso;

71 MONTENEGRO FILHO, Misael. Novo Código de Processo Civil Comentado, 2. ed. São Paulo: Editora Atlas, 2016, p. 765. 
II - de cônjuge, de companheiro ou de qualquer parente do morto, consanguíneo ou afim, em linha reta ou na linha colateral em segundo grau, no dia do falecimento e nos 7 (sete) dias seguintes;

III - de noivos, nos 3 (três) primeiros dias seguintes ao casamento; IV - de doente, enquanto grave o seu estado.

As situações indicadas nos quatro incisos impõem respeito às pessoas nelas envolvidas. Ou seja, salvo para evitar perecimento de direito, o oficial de justiça não poderá promover a citação do réu, sob pena de invalidade do ato processual.

Na mesma direção de garantia da dignidade da pessoa humana, aponta-se o artigo 404 do novo diploma processual. Vejamos:

Artigo 404. A parte e o terceiro se escusam de exibir, em juízo, o documento ou a coisa se:

I - concernente a negócios da própria vida da família;

II - sua apresentação puder violar dever de honra;

III - sua publicidade redundar em desonra à parte ou ao terceiro, bem como a seus parentes consanguíneos ou afins até o terceiro grau, ou lhes representar perigo de ação penal;

IV - sua exibição acarretar a divulgação de fatos a cujo respeito, por estado ou profissão, devam guardar segredo; $\mathrm{V}$ - subsistirem outros motivos graves que, segundo o prudente arbítrio do juiz, justifiquem a recusa da exibição;

VI - houver disposição legal que justifique a recusa da exibição.

Parágrafo único. Se os motivos de que tratam os incisos I a VI do caput disserem respeito a apenas uma parcela do documento, a parte ou o terceiro exibirá a outra em cartório, para dela ser extraída cópia reprográfica, de tudo sendo lavrado auto circunstanciado.

Tal regra tem por escopo concretizar o artigo $5^{\circ}$., inc. $\mathrm{X}$, da $\mathrm{CF}$, que dispõe que "são invioláveis a intimidade, a vida privada, a honra 
e a imagem das pessoas, assegurado o direito a indenização pelo dano material ou moral decorrente de sua violação".

Nos incisos do artigo 404, tem-se, em primeiro lugar, a escusa quando o documento ou a coisa for relativo a negócios da própria vida da família. Seriam exemplos os diários pessoais e álbuns de fotografias. Outra causa seria a escusa na exibição de documento fundada na violação de dever de honra. A respeito do tema, pondera Leonardo Greco: ${ }^{72}$

Sendo um dever muito abstrato, impreciso, ninguém pode dele se valer tão somente para ocultar fatos ou documentos que comprovam o direito de outrem. Caso contrário, tal situação implicaria reconhecer que alguém pudesse criar um obstáculo à apuração da verdade que interesse a outrem, ferindo o direito à tutela jurisdicional efetiva.

O inciso III do artigo em análise, por sua vez, contempla ainda a escusa de exibição do documento ou coisa quando a sua publicidade representar à parte, ao terceiro, ou a seus parentes consanguíneos ou afins até o terceiro grau desonra ou perigo de ação penal. Nesse caso, o diploma processual civil assentou o direito à não autoincriminação previsto no artigo $5^{\circ}$., LXIII, da CF/88 e possibilitou a recusa de exibição para não incriminar parentes, em homenagem à solidariedade e preservação da família.

A escusa por sigilo profissional, a seu turno, está prevista no inciso IV do artigo 404. É o caso do advogado, que possui a prerrogativa de "recusar-se a depor como testemunha em processo no qual funcionou ou deva funcionar, ou sobre fato relacionado com pessoa de quem seja ou foi advogado, mesmo quando autorizado ou solicitado pelo constituinte, bem como sobre fato que constitua sigilo profissional" (art. $7^{\circ}$, XIX, da Lei n. 8.906/94).

72 GRECO, Leonardo. Instituições de processo civil. Rio de Janeiro: Forense, 2010 , p. 223, v. II. 
Em outra direção, o inciso V do artigo 404 do CPC/2015 deixa em aberto maior margem de liberdade para que o magistrado, no momento de decidir, quanto à aceitação da recusa da exibição do documento ou coisa, verifique qualquer motivo grave.

Além disso, o inc. VI do artigo 404 do CPC/1988 acrescenta que a parte ou o terceiro se escusam de exibir o documento ou a coisa quando houver disposição legal que justifique a recusa de exibição. Eduardo Cambi ${ }^{73}$ exemplifica tal previsão no seguinte caso:

[...] o art. 5 $5^{\circ}$, XXXIII, da CF/1988 garante o direito fundamental a receber dos órgãos públicos informações de seu interesse particular, ou de interesse coletivo ou geral, ressalvadas aquelas cujo sigilo for imprescindível à segurança da sociedade e do Estado. A Lei $12.527 / 2011$ restringe o acesso às informações quanto a dados pessoais - relativos à intimidade, vida privada, honra e imagem, a agentes públicos legalmente autorizados, à pessoa a que eles se referirem ou a terceiros, desde que haja previsão legal ou consentimento expresso da pessoa (art. 31 , caput e $\S 1^{\circ}$.) - ou às informações classificadas por autoridades como sigilosas (arts. 23 e $24, \S 2^{\circ}$.).

Seja como for, a possibilidade de recusa encontra limites nos termos do artigo 399 do CPC. A recusa será inadmissível, por exemplo: (i) se o requerido tiver obrigação legal de exibir; (ii) se o requerido tiver aludido ao documento ou à coisa, no processo, com o intuito de constituir prova $\mathrm{e}$ (iii) se o documento, por seu conteúdo, for comum às partes.

De qualquer modo, é possível que o juiz tenha que ponderar, em concreto, acerca de bens jurídicos em conflito. De um lado, é possível que o artigo 399 ordene a exibição. De outro, o artigo 404 sobreleve uma garantia inafastável. Diante disso, certamente os postulados da proporcionalidade e da razoabilidade servirão de norte para que o ma-

${ }_{73}$ CAMBI, Eduardo. Código de Processo Civil Comentado. São Paulo: Revista dos Tribunais, 2016, RT PROVIEW. 
gistrado tome a decisão mais consentânea com o processo que respeita a dignidade da pessoa humana.

Em outro giro, indica-se, ainda, o artigo 139, inc. IV, do novo Diploma Processual, a saber:

Artigo 139. O juiz dirigirá o processo conforme as disposições deste Código, incumbindo-lhe:

[omisso]

IV - determinar todas as medidas indutivas, coercitivas, mandamentais ou sub-rogatórias necessárias para assegurar o cumprimento de ordem judicial, inclusive nas ações que tenham por objeto prestação pecuniária.

Tal norma tem por escopo a efetividade processual. A mera declaração de uma decisão judicial, por vezes, não impõe a satisfação jurisdicional completa. É necessário, pois, que as decisões jurisdicionais, sejam de que natureza for (declaratórias, constitutivas, condenatórias, mandamentais ou executivas), sejam cumpridas, isto é, efetivadas.

Nesse sentido, é dever do juiz, consoante a inteligência do artigo 139, inc. IV, determinar todas as medidas necessárias para assegurar o cumprimento de ordem judicial. Evidente que pela redação do texto legal, o referido inciso encerra verdadeira cláusula geral para o magistrado, de modo que, ao menos em tese, "o juiz pode e deve se valer de um conjunto de providências, nominadas ou não, voltadas a atribuir concretude às ordens que emitir em decorrência de pronunciamentos provisórios ou definitivos". ${ }^{74}$

As atribuições deste inciso, alerta Jonatas Luiz Moreira de Paula: ${ }^{75}$

[...] não somente servem para o desenvolvimento da relação processual e efetivação do direito reconheci-

74 MACIEL, Daniel Baggio. Comentários ao Código de Processo Civil. Coordenadores: Angélica Arruda Alvim... [et al.]. São Paulo: Saraiva, 2016, p. 214.

75 PAUlA, Jonatas Luiz Moreira de. Código de Processo Civil Comentado. Coordenadores: Eduardo Cambi... [et al.]. São Paulo: Revista dos Tribunais, 2016, RT PROVIEW. 
do, como também podem ser destinadas ao combate de atos contrários à dignidade da justiça e às medidas meramente protelatórias. Portanto, trata-se de eficiente ferramenta jurídica disposta ao juiz a fim de preservar o correto andamento do processo.

Entretanto, ao não especificar quais são as medidas que o juiz pode levar a cabo, o novo estatuto processual abriu uma margem para que o juiz decida conforme a sua inteligência. Todavia e evidentemente, essas providências precisam ser adequadas para a concretização do comando judicial. Não obstante, a medida a ser implementada deve, necessariamente, ser proporcional à finalidade perseguida, sob pena de exceder-se o estritamente necessário para uma tutela efetiva do direito.

Nessa direção é o magistério de Roberto Sampaio Contreiras de Almeida: ${ }^{76}$

76 ALMEIDA, Roberto Sampaio Contreiras de. Breves Comentários ao Novo Código de Processo Civil. Coordenadores: Teresa Arruda Alvim Wambier... [et al.]. São Paulo: Editora Revista dos Tribunais, 2016, [livro eletrônico]. 
tagens de sua aplicação, buscando a solução que melhor atenda aos valores em conflito (MARCELO LIMA GUERRA. Direitos fundamentais e a proteção do credor na execução civil. São Paulo: Ed. RT, 2003. p. 127).

De todo modo, o dispositivo em exame não pode, sob pena de puro arbítrio e autoritarismo, restringir direitos fundamentais com o propósito utilitarista de se ter um processo efetivo. $\mathrm{O}$ artigo $8^{\circ}$. do novo CPC impõe, pois, que as medidas utilizadas pelo juiz (art. 139, inc. IV) resguardem e promovam a dignidade da pessoa humana, tendo como nortes para se tomar uma providência justa os princípios da proporcionalidade e da razoabilidade.

Nesse passo ainda, o professor Fredie Didier Jr. também acrescenta, como bons exemplos paradigmáticos da promoção da dignidade da pessoa humana no processo civil contemporâneo, o direito do portador de deficiência auditiva a comunicar-se, em audiências, por meio da Língua Brasileira de Sinais (art. 162, III); a consagração da atipicidade da negociação processual (art. 190, CPC); direito ao silêncio no processo civil (art. 388, CPC) e a humanização do processo de interdição (arts. $\left.751, \S 3^{\circ} ., 755, \mathrm{II}\right) .^{77}$

Quanto à primeira norma, pode-se inferir que, quando qualquer das partes ou testemunhas se comunicar, apenas, por meio da Língua Brasileira de Sinais, ou equivalente, caberá ao juiz designar intérprete para converter essa linguagem para o português, por escrito, para documentá-la nos autos. Essa é uma importante função inclusiva que resguarda a dignidade daqueles que necessitam de um tratamento processual diferenciado.

De outro lado, o artigo 190 do Código de Processo Civil consagra o princípio de respeito ao autorregramento da vontade no processo, impondo uma nova compreensão da regra do impulso oficial. É que, agora, é possível que as partes reestruturem, de forma negocial, o andamento do processo. Nesse sentido, o novo CPC traz uma cláusula

77 CABRAL, Antonio Passo, CRAMER, Ronaldo (orgs.). Comentários ao Novo Código de Processo Civil. Forense, 2015, p. 31. 
geral de negócios processuais. Trata-se, nas lições de Alexandre Freitas Câmara, "da genérica afirmação da possibilidade de que as partes, dentro de certos limites estabelecidos pela própria lei, celebrem negócios através dos quais dispõem de suas posições processuais". ${ }^{78}$

Assim, conforme Leonardo Carneiro da Cunha:

Por ser a liberdade um direito fundamental que consiste numa das dimensões da dignidade humana e por ter o CPC prestigiado a autonomia da vontade das partes (art. 190), a promoção judicial da dignidade humana encontra limite no exercício do poder de autorregramento processual das partes, que podem não querer aceitar um comportamento mais ativo do órgão julgador. ${ }^{79}$

Seguindo o mesmo passo de humanização do processo civil, aponta-se ainda o direito ao silêncio previsto no artigo 388. Tal preceito anuncia um valor muito caro para o sistema processual, que é a garantia outorgada às partes de não produzir prova contra si, prevista no artigo 379, I, do novo CPC (nemo tenetur se detegere).

Daí que, relativamente ao depoimento pessoal, o artigo 388, adotando um rol mais amplo que o previsto no CPC/73 (art. 347), libera o silêncio da parte a respeito de fatos criminosos ou torpes, fatos abrangidos pelo sigilo profissional, fatos impregnados de um potencial de desonra própria, de seu cônjuge ou companheiro ou de parente em grau sucessível (ascendentes, descendentes e colaterais até $4^{\circ}$. grau). A escusa também é legítima quando os fatos objeto de questionamento gerem perigo à vida do depoente ou das pessoas já indicadas. Andou bem, pois, o novo Código de Processo Civil, preservando a dignidade das partes que prestam depoimento em juízo.

78 CÂMARA, Alexandre Freitas. O Novo Processo Civil Brasileiro, 2 ed. São Paulo: Atlas, 2016, p. 124.

79 CUNHA, Leonardo Carneiro da. Artigo 8 . In: __. STRECK, Lenio; NUNES, Dierle (orgs.). Comentários ao código de Processo Civil. São Paulo: Saraiva, 2016, p. 46. 
Nada obstante, os artigos 751, $\S 3^{\circ}$. e 755 , II inauguram um modelo de interdição mais humano. A primeira norma estabelece que "durante a entrevista, é assegurado o emprego de recursos tecnológicos capazes de permitir ou de auxiliar o interditando a expressar suas vontades e preferências e a responder às perguntas formuladas". O comando legal reveste-se de natureza pedagógica, reforçando a natureza personalíssima da entrevista, na qual o juiz coletará as suas impressões sobre a situação da pessoa do interditando.

O segundo preceito, por sua vez, estatui que o juiz, na sentença que decretar a interdição, "considerará as características pessoais do interdito, observando suas potencialidades, habilidades, vontades e preferências". Tais mandamentos, não se olvida, se curvam à priorização da preservação dos direitos fundamentais da pessoa humana em face da instrumentalidade do processo. Percebe-se, portanto, que as normas processuais sobreditas enaltecem as subjetividades daqueles que participam dos litígios processuais.

Vê-se, por tudo o que foi exposto, que a dignidade da pessoa humana veda, no processo civil, a transformação das partes em objeto da atividade jurisdicional. ${ }^{80}$ É por esse motivo que a dignidade humana tem estreito relacionamento com o direito de participação das partes na construção das decisões jurisdicionais, tanto na previsão do direito ao contraditório pleno como direito de influência (arts. 9 e 10, NCPC), tanto no dever de fundamentação como no dever de debate (arts. $11 \mathrm{e}$ $489, \S \S 1^{\circ}$. e $2^{\circ}$., NCPC). ${ }^{81}$

É nesse sentido que Marinoni, Mitidiero e Arenhart atestam que:

O juiz ao aplicar o ordenamento jurídico e ao conduzir o processo deve resguardar e promover a dignidade da pessoa humana, o que significa encarar o processo

80 MARINONI, Luiz Guilherme; MITIDIERO, Daniel; ARENHART, Sérgio Cruz. Novo Código de Processo Civil comentado, 2. ed. São Paulo: Editora Revista dos Tribunais, 2016, p. 37.

81 MARINONI, Luiz Guilherme; MITIDIERO, Daniel; ARENHART, Sérgio Cruz. Novo Código de Processo Civil comentado, 2. ed. São Paulo: Editora Revista dos Tribunais, 2016, p. 37. 
como um meio para tutela dos direitos, respeitar a liberdade das partes nos seus espaços de autodeterminação e adotar o contraditório como método de trabalho. ${ }^{82}$

Não é outro o magistério do Professor Leonardo Carneiro da Cunha, para o qual:

Um processo devido, adequado, eficiente, justo, équo, é um processo que atende à dignidade humana, conferindo tratamento digno às partes e aos demais sujeitos processuais. Um processo em que se assegurem o contraditório, a boa-fé, a imparcialidade, a publicidade, a exigência de fundamentação e, enfim, que respeite as garantias fundamentais do processo atende à dignidade humana. ${ }^{83}$

Destarte, valendo-se das lições de Luiz Fux, o processo civil inaugura um tempo constitucional e humano, na medida em que o juiz, ao solucionar uma questão humana, deverá partir sempre da primazia da dignidade da pessoa humana na interpretação, não só do mérito ou do direito material, mas, também, das regras processuais. ${ }^{84}$

\section{CONSIDERAÇÕES FINAIS}

Não se duvida que o processo é essencialmente instrumental. Todavia, dada a sua importância para a resolução do justo direito, o processo civil é encarregado de salvaguardar os interesses dos cidadãos, de modo que deve ser estruturado, interpretado e aplicado de forma capaz de garantir a dignidade humana das partes que litigam em juízo. O novo

82 IBIDEM, p. 38.

83 CUNHA, Leonardo Carneiro da. Artigo $\mathbf{8}^{\mathbf{0}}$. In: . STRECK, Lenio; NUNES, Dierle (orgs.). Comentários ao código de Processo Civil. São Paulo: Saraiva, 2016, p. 47.

84 FUX, Luiz. O Novo Processo Civil Brasileiro. Direito em expectativa. Rio de Janeiro: Forense, 2011, p. 14. 
Código de Processo Civil estabelece-se como um instrumento capaz de transformar direitos fundamentais em verdadeira tutela justa, orientada e tendo por fim último a pessoa humana.

A construção, portanto, de uma principiologia processual em torno da dignidade humana "pode ajudar na humanização do processo civil, ou seja, na construção de um processo civil atento a problemas reais que afetem a dignidade do indivíduo". ${ }^{85}$

Nessa direção, o artigo $8^{\circ}$. do NCPC é guia hermenêutico para as resoluções das celeumas processuais, de modo que o magistrado - e por que não, todos os sujeitos processuais - deve atentar-se para resguardar e promover a dignidade da pessoa humana. Ademais, há uma infinidade de preceitos normativos que se relacionam, direta ou indiretamente, com a proteção e efetivação da humanidade processual.

Inobstante, a par das diversas melhorias trazidas pelo novo diploma processual, não se pode esperar que o processo se torne automaticamente perfeito e garantidor dos direitos fundamentais e da dignidade da pessoa humana. No momento, ainda recente de vigência do NCPC, está-se diante de law in books. É chegada a hora, entretanto, da aplicação dos ditames e postulados constitucionais, a se ver verdadeiro law in action. Nesse sentido, Humberto Theodoro Jr. atenta para o fato de que "entre a mudança da norma e a transformação da realidade dos serviços judiciários vai uma distância muito grande". ${ }^{86}$

A despeito disso, entretanto, vê-se com bons olhos as novas águas que margeiam o Código de Processo Civil de 2015, enaltecendo-se a abertura democrática, a principiologia constitucional a lhe nortear, a profusão de garantias e direitos fundamentais processuais, conferindo-se, em última análise, um processo devido, justo e digno, com respeito, com o perdão da redundância, à dignidade da pessoa humana, fim último do direito material e do direito processual.

85 CABRAL, Antonio Passo, CRAMER, Ronaldo (orgs.). Comentários ao Novo Código de Processo Civil. Forense, 2015, p. 37.

86 THEODORO JÚNIOR, Humberto. Curso de Direito Processual Civil - Volume I. São Paulo: Atlas, 2016, p. 38. 
Conclui-se, ao fim, valendo-se do magistério preciso de Cândido Dinamarco, porque atualíssimo:

\begin{abstract}
Não tem acesso à justiça aquele que sequer consegue fazer-se ouvir em juízo, como também todos os que, pelas mazelas do processo, recebem uma justiça tarda ou alguma injustiça de qualquer ordem. Augura-se a caminhada para um sistema em que reduzam ao mínimo inevitável os resíduos de conflitos não-jurisdicionalizáveis (universalizar a tutela jurisdicional) e em que o processo seja capaz de outorgar a todo aquele que tem razão toda a tutela jurisdicional a que tem direito. ${ }^{87}$
\end{abstract}

\title{
REFERÊNCIAS
}

AGRA, Walber de Moura. Curso de Direito Constitucional, 7. ed. Rio de Janeiro: Forense, 2012.

ALVIM, Angélica Arruda... [et al.]. Comentários ao Código de Processo Civil. São Paulo: Saraiva, 2016.

ALVIM, Thereza Arruda. O Novo Código de Processo Civil Brasileiro - Estudos Dirigidos: Sistematização e Procedimentos. Rio de Janeiro: Forense, 2015.

BARROSO, Luís Roberto. Interpretação e aplicação da Constituição, 4. ed. São Paulo: Saraiva, 2001.

BONICIO, Marcelo Magalhães. Os princípios do processo no novo código de processo civil, 1. ed. São Paulo: Saraiva, 2016.

BOTELHO, Guilherme. Direito ao processo qualificado: o processo civil na perspectiva do Estado Constitucional. Porto Alegre: Livraria do Advogado, 2010 .

BUENO, Cassio Scarpinella. Manual de processo civil: baseado no novo código de processo civil, 1. ed. São Paulo: Saraiva, 2015.

87 DINAMARCO, Cândido Rangel. A Reforma da Reforma. SP: Malheiros, 2002, 2. ed., p. 37. 
CABRAL, Antonio Passo, CRAMER, Ronaldo (orgs.). Comentários ao Novo Código de Processo Civil. Rio de Janeiro: Forense, 2015.

CÂMARA, Alexandre Freitas. O Novo Processo Civil Brasileiro, 2. ed. São Paulo: Atlas, 2016.

CAMBI, Eduardo. Neoconstitucionalismo e Neoprocessualismo. Panóptica, 2007, p. 2. Disponível em: <http://www.panoptica.org/seer/index.php/op/article/view/Op_2.2_2007_1-44/64>. Acesso em 25 de maio de 2016.

CAMBI, Eduardo et al. Código de Processo Civil Comentado. São Paulo: Revista dos Tribunais, 2016, RT PROVIEW.

CARMONA, Carlos Alberto et al. O Novo Código de Processo Civil: questões controvertidas. São Paulo: Atlas, 2015.

DIDIER JR, Fredie. Curso de direito processual civil. Teoria geral do processo e processo de conhecimento, 6. ed. Salvador: JusPodivm, 2006, v. 1.

DINAMARCO, Cândido Rangel. A Reforma da Reforma. SP: Malheiros, 2002.

DONIZETTI, Elpídio. Novo código de processo civil comentado (Lei $\mathrm{n}^{\circ}$. 13.105, de 16 de março de 2015): análise comparativa entre o novo CPC e o CPC/73. São Paulo: Atlas, 2015.

FERNANDES, Bernardo Gonçalves. Curso de Direito Constitucional, 3. ed. Salvador: Juspodvim, 2013.

FUX, Luiz. O Novo Processo Civil Brasileiro. Direito em expectativa. Rio de Janeiro: Forense, 2011.

GADAMER, Hans-Georg. Verdade e Método: traços fundamentais de uma hermenêutica filosófica. Tradução Flávio Paulo Meurer, 2. ed. Petrópolis: Editora Vozes, 1998.

GRECO, Leonardo. Instituições de processo civil. Rio de Janeiro: Forense, 2010 , p. 223, v. II.

HESSE, Konrad. Elementos de direito constitucional da República Federal da Alemanha. Trad. Luís Afonso Heck. Porto Alegre: Sergio Antonio Fabris Editor, 1998. 
Jr., MACHADO, Dario Ribeiro, CARNEIRO, Paulo Pinheiro, PINHO, Humberto Dalla de. Novo Código de Processo Civil - Anotado e Comparado. Rio de Janeiro: Forense, 2015.

MARINONI, Luiz Guilherme; MITIDIERO, Daniel. O projeto do CPC: críticas e propostas. São Paulo: Revista dos Tribunais, 2010.

MARINONI, Luiz Guilherme; MITIDIERO, Daniel; ARENHART, Sérgio Cruz. Novo Código de Processo Civil comentado, 2. ed. São Paulo: Editora Revista dos Tribunais, 2016.

MEDEIROS NETO, Elias Marques de. $\mathrm{O}$ artigo $4^{\circ}$. do novo Código de Processo Civil e o princípio da efetividade do processo. In: Reflexões sobre o novo Código de Processo Civil Orgs. Geisa de Assis Rodrigues, Robério Nunes dos Anjos Filho. Brasília: ESMPU, 2016, v. 1.

MEDINA, José Miguel Garcia. Novo Código de Processo Civil comentado, 1. ed. São Paulo: Editora Revista dos Tribunais, 2015.

MITIDIERO, Daniel. Colaboração no processo civil: pressupostos sociais, lógicos e éticos, 2. ed. São Paulo: Revista dos Tribunais, 2011.

MONTENEGRO FILHO, Misael. Novo Código de Processo Civil Comentado, 2. ed. São Paulo: Editora Atlas, 2016.

ROSENVALD, Nelson. A dignidade da pessoa humana no CPC/15. Disponível em: <http://www.nelsonrosenvald.info/\#!A-dignidade-da-pessoa-humana-no-CPC15/c21xn/567465c30cf2c2b7798a7adc>. Acesso em 12 jun. 2016.

2005.

Dignidade humana e boa-fé no Código Civil. São Paulo: Saraiva,

SARLET, Ingo Wolfgang. Dignidade da Pessoa Humana e Direitos Fundamentais na Constituição de 1988. Porto Alegre: Livraria do Advogado, 2001.

SARMENTO, Daniel. A ponderação de interesses na Constituição Federal, 1. ed. - segunda tiragem. Rio de Janeiro: Lumen Juris, 2002.

STRECK, Lenio Luiz; CUNHA, Leonardo Carneiro da; NUNES, Dierle (orgs.). Comentários ao código de Processo Civil. São Paulo: Saraiva, 2016. THEODORO JÚNIOR, Humberto. Novo Código de Processo Civil Anotado, 20. ed. Rio de Janeiro: Forense, 2016. 
. O Compromisso do Projeto de Novo Código de Processo Civil com

o processo justo. Revista de Informação Legislativa, 2011.

. Curso de Direito Processual Civil - Volume I. São Paulo: Atlas, 2016.

WAMBIER, Teresa Arruda Alvim. Primeiros comentários ao novo código de processo civil. São Paulo: Editora Revista dos Tribunais, 2016.

WAMBIER, Teresa Arruda Alvim... [et al.]. Breves Comentários ao Novo Código de Processo Civil. Coordenadores: São Paulo: Editora Revista dos Tribunais, 2016, [livro eletrônico].

\section{Dados dos Autores}

\section{Elias Marques Medeiros Neto}

Professor do mestrado e doutorado em Direito da Universidade de Marília, UNIMAR, Marília/SP - Brasil. Pós-doutor em Direito pela Universidade de São Paulo, USP/SP - Brasil. Pós-doutor em Direito pela Universidade de Lisboa, Portugal. Doutor e Mestre em direito pela Pontifícia Universidade Católica de São Paulo, PUC, São Paulo/SP - Brasil. Elias.Marques@cosan.com.

\section{André Medeiros Toledo}

Graduado em Direito pela Universidade Federal da Paraíba, UFPB, João Pessoa/PB - Brasil. Mestrando em Direito pela Universidade de Marília, UNIMAR, Marília/SP - Brasil. Tabelião de Notas em São Paulo/SP, no $19^{\circ}$ Tabelionato de Notas da capital. andretoledojp@hotmail.com.

Submetido em: 16-03-2017

Aceito em: 24-04-2017 